DOI 10.4467/25439561KSR.19.001.11303

\author{
MARIUSZ KowALSKI (D) https://orcid.org/0000-0003-3417-0369 \\ Instytut Geografii i Przestrzennego Zagospodarowania PAN \\ Warszawa
}

\title{
GEOGRAFIA ŚREDNIOWIECZNEJ SŁOWIAŃSZCZYZNY
}

\author{
GEOGRAPHY OF MEDIEVAL SLAVDOM
}

\begin{abstract}
Streszczenie
W wyniku średniowiecznej ekspansji Słowianie zasiedlili 1/3 Europy. Geografia tego osadnictwa i jego politycznej organizacji jest dobrze rozpoznana dla czasów środkowego i późnego średniowiecza. Znacznie mniej wiadomo na temat pierwotnej ojczyzny Słowian, jak również przebiegu ich ekspansji we wczesnym średniowieczu. Jest to pożywka dla wielu, często wykluczających się, koncepcji. Rozwój poszczególnych dyscyplin badawczych (archeologia, językoznawstwo, genealogia genetyczna) przynosi jednak nowe możliwości poznawcze. Koncepcje allochtonistów i autochtonistów nie muszą być sprzeczne, lecz mogą przynosić uzupełniającą się wiedzę. Umieszczenie siedzib Prasłowian w dorzeczu Wisły i Odry wcale nie musi wykluczać ukształtowania podstaw słowiańskiego etosu w jego ostatecznej postaci w dorzeczach Prypeci, Bohu i Dniestru. Ta nowa jakość kulturowa mogła być jednak rozprzestrzeniania przy współudziale całej prasłowiańskiej ludności, a istotną rolę w tym procesie mogła również odegrać wtórna migracja niektórych plemion słowiańskich znad Dunaju.
\end{abstract}

\section{Abstract}

As a result of the medieval expansion, Slavs settled 1/3 of Europe. The geography of this settlement and its political organization is well known for the Middle and Late Middle Ages. Much less is known about the original homeland of Slavs, as well as the course of their expansion in the early Middle Ages. It is a medium for many concepts, often contradictory to each other. However, the development of individual research disciplines (archeology, lin-

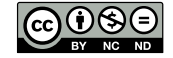


guistics, genetic genealogy), brings new cognitive abilities. Allochtonist and autochthonist concepts do not have to be at all contradictory, but bring complementary knowledge. Placing the seats of the Proto-Slavs in the basins of the Vistula and the Oder, does not necessarily exclude shaping the foundations of Slavic ethnos in its final form in the basins of Pripyat, Boh and Dniester. This new cultural quality could, however, be spread with the participation of the Proto-Slavic population, and an important role in this process could also be played by the secondary migration of some Slavic tribes from the Danube Valley.

Słowa kluczowe: Słowianie, pierwotne siedziby, ekspansja, strefy osadnicze, asymilacja Keywords: Slavs, primary settlement, expansion, settlement zones, assimilation

\section{Wstęp}

Początek średniowiecza to czas rozprzestrzeniania się plemion słowiańskich po rozległych obszarach Europy Środkowo-Wschodniej. Na zachodzie Słowianie dotarli w okolice Hamburga, na południu na Peloponez i do Bitynii w Azji Mniejszej, a na wschodzie w dorzecze górnej Wołgi ${ }^{1}$.

Uznając za Europę Półwysep Europejski, rozciągający się na zachód od najkrótszej linii łączącej Morze Azowskie z Morzem Białym (a więc na zachód od działu wodnego Dniepr-Wołga), można przyjąć, że Słowianie zasiedlili we wczesnym średniowieczu około 1/3 obszaru Europy, a nawet wyszli poza nią (dorzecze Wołgi, Azja Mniejsza). W Europie Wschodniej zaś (na wschód od Łaby) stali się etnosem dominującym.

Analizując ostateczny zasięg słowiańskiego osadnictwa, będący efektem ekspansji osadniczej - zarejestrowanej i w dużym stopniu udokumentowanej przez dawnych kronikarzy (szczególnie na Bałkanach) - nie można uciec od pytania, jakie obszary zajmowali Słowianie przed swoją wczesnośredniowieczną wędrówką, co łączy się bardzo często z dyskusją na temat miejsca i czasu etnogenezy Słowian. Tu jednak napotykamy na bardzo poważne luki w naszej wiedzy, choć zagadnieniem tym zajmują się od dłuższego czasu specjaliści reprezentujący różne dziedziny nauki.

Niniejsze opracowanie koncentruje się w związku z tym na rekonstrukcji siedzib słowiańskich we wczesnym średniowieczu, procesie ekspansji, zjawisku slawizacji ludów autochtonicznych oraz akulturacji Słowian na niektórych obszarach. Geografia ustabilizowanych siedzib plemion słowiańskich po okresie wędrówek jest dobrze przebadana, nie budzi dużych kontrowersji i można się z nią zapoznać w opracowa-

\footnotetext{
I L. Leciejewicz, Mały słownik kultury dawnych Słowian, Warszawa, Wiedza Powszechna, 1988.
} 
niach takich autorów, jak: Zofia Kurnatowska ${ }^{2}$, Jerzy Strzelczyk ${ }^{3}$, Lech Leciejewicz ${ }^{4}$, Tadeusz Wasilewski ${ }^{5}$, Henryk Paszkiewicz ${ }^{6}$, Henryk Łowmiański ${ }^{7}$, Jan Tyszkiewicz ${ }^{8}$. To samo dotyczy późnośredniowiecznych monarchii słowiańskich oraz Słowian w niesłowiańskich organizmach państwowych.

\section{Ojczyzna Słowian}

Punktem wyjściowym badań nad geografią średniowiecznej Słowiańszczyzny powinna być identyfikacja siedzib Słowian z przełomu starożytności i średniowiecza, z okresu poprzedzającego ich wczesnośredniowieczną ekspansję. W tej sprawie badacze opowiadają się generalnie za dwoma koncepcjami: autochtoniczną i allochtoniczną. Stanowiska ich zwolenników wywołują czasami zażarty spór, których przedmiot, a często nawet i styl, został już wielokrotnie opisany9 . Autochtoniści sytuują kolebkę Słowiańszczyzny w dorzeczu Wisły i Odry, allochtoniści w dorzeczu Dniepru. Są jednak i tacy (np. Jerzy Strzelczyk ${ }^{10}$ ), którzy łączą oba te podejścia, widząc ojczyznę Słowian pomiędzy Odrą a Dnieprem, jak i inni, którzy sytuują ją poza tymi obszarami (dorzecze Dunaju, Azja ${ }^{11}$ ). W Polsce, za sprawą Kazimierza Godłowskiego, od końca lat 70. XX wieku szczególną popularnością cieszy się teoria allochtoniczna $^{12}$, ale wciąż także swoje argumenty przedstawiają zwolennicy innych

2 Z. Kurnatowska, Słowiańszczyzna południowa, Wrocław, Ossolineum, 1977.

3 J. Strzelczyk, Stowianie połabscy, Poznań, Wydawnictwo Poznańskie, 2002.

${ }^{4}$ L. Leciejewicz, Stowianie Zachodni: z dziejów tworzenia się średniowiecznej Europy, Wrocław, Ossolineum, 1989.

5 J. Skowronek, M. Tanty, T. Wasilewski, Historia Stowian poludniowych i zachodnich, Warszawa, PWN, 1988.

${ }^{6}$ H. Paszkiewicz, Początki Rusi, Kraków, Polska Akademia Umiejętności, 1996.

${ }^{7}$ H. Łowmiański, Studia nad dziejami Stowiańszczyzny, Polski i Rusi w wiekach średnich, Poznań, Uniwersytet im. Adama Mickiewicza w Poznaniu, 1986.

8 J. Tyszkiewicz, Geografia historyczna Polski w średniowieczu, Warszawa, DiG, 2003.

9 J. Strzelczyk, Od Prastowian do Polaków, Kraków, KAW, 1987; L. Leciejewicz, Stowianie Zachodni..., op. cit.; M. Noińska, Genetyka populacyjna a problem etnogenezy Stowian, „Studia Rossica Gedanensia" 2016, nr 3, ss. 143-156; K. Borowiec, Kanon wiedzy na temat tzw. etnogenezy Stowian. Czas przełomu, „Kwartalnik Językoznawczy” 2012, nr 1, ss. 1-37.

10 J. Strzelczyk, Od Prastowian ..., op. cit.; L. Leciejewicz, Stowianie Zachodni..., op. cit.; M. Parczewski, Idzie nowe. Pierwsi Stowianie na ziemiach Polski, [w:] A. Bursche (red.), Barbarzyńskie tsunami. Okres Wędrówek Ludów w dorzeczu Odry i Wisty, Warszawa-Szczecin, Uniwersytet Warszawski, Muzeum Narodowe w Szczecinie, 2017, ss. 59-65.

${ }^{11}$ K. Moszyński, Badania nad pochodzeniem i pierwotna kultura Stowian, t. I, Kraków, PAU, 1925.

${ }^{12}$ K. Godłowski, Pierwotne siedziby Stowian: wybór pism, M. Parczewski (red.), Kraków, Instytut Archeologii Uniwersytetu Jagiellońskiego, 2000; A. Kokowski, Starożytna Polska. Od trzeciego stulecia przed narodzeniem Chrystusa do schyłku starożytności, Warszawa, Wydawnictwo Trio, 2005, s. 532. 
lokalizacji słowiańskiej praojczyzny ${ }^{13}$. Jest to możliwe, ponieważ każda z koncepcji posiada słabe punkty, które zachęcają do poszukiwania alternatywnych rozwiązań. $\mathrm{Na}$ tej podstawie można sądzić, że w kwestii ojczyzny Słowian nie powiedziano jeszcze ostatniego słowa. Tym bardziej, że rozwój różnych dyscyplin badawczych przynosi nowe możliwości analiz naukowych.

\section{Źródła}

Cenną, choć ubogą, skarbnicą wiedzy o dawnych Słowianach są źródła pisane. Pierwszy raz etnonim przypominający nazwę Słowian - Suowenoi - wymieniony zostaje przez Klaudiusza Ptolemeusza dla opisaniu ludu, który w II w. n.e. miał zamieszkiwać górne dorzecze Wołgi. Tak odległe umieszczenie tej nazwy każe jednak badaczom powątpiewać, by mogła mieć ona cokolwiek wspólnego z późniejszymi Słowianami ${ }^{14}$. Do tej lokalizacji można by dopasować jedynie takie poglądy, jakie prezentował np. Kazimierz Moszyński, stawiający tezę o pochodzeniu Słowian z Azji Środkowej ${ }^{15}$. Jego zdaniem mieli oni jednak przybyć w dorzecze Dniepru kilkaset lat p.n.e. ${ }^{16}$, więc Ptolemeusz powinien ich umiejscowić już w tym nowym położeniu. Czysto teoretycznie można by jednak założyć trochę inną chronologię ich wędrówki niż proponował to K. Moszyński i postawić hipotezę o pojawieniu się nadwołżańskich „Słowian” w bliskości ich docelowych siedzib np. z chwilą narodzin archeologicznej kultury prasko-korczakowskiej, kojarzonej z początkami średniowiecznej Słowiańszczyzny. Współgrałoby to z trudnościami, jakie napotykają archeolodzy w znalezieniu miejscowych źródeł tej kultury (patrz dalej).

13 W. Mańczak, Zagadnienie praojczyzny Stowian, „Przegląd Historyczny” 2003, nr 1, ss. 77-81; Z. Babik, Najstarsza warstwa nazewnicza na ziemiach polskich $w$ granicach wczesnośredniowiecznej Słowiańszczyzny, Kraków, Universitas, 2001; L. Leciejewicz, Stowianie Zachodni..., op. cit.; J. Nalepa, O pierwotnych siedzibach Stowian $w$ świetle nowszych badań archeologicznych, lingwistycznych $i$ historycznych, „Slavia Antiqua: rocznik poświęcony starożytnościom słowiańskim” 2007, nr 48, ss. $11-$ 96; T. Makiewicz, W sprawie aktualnego stanu badań nad problemem kontynuacji kulturowej pomiędzy starożytnościa a wczesnym średniowieczem w Polsce. Punkt widzenia autochtonisty, „Slavia Antiqua: rocznik poświęcony starożytnościom słowiańskim" 2005, nr 46, ss. 9-38; J. Piontek, B. Iwanek, S. Segeda, Antropologia o pochodzeniu Słowian, Poznań, Monografie Instytutu Antropologii UAM, 12, 2008; M. Mielnik-Sikorska et al., The History of Slavs Inferred from Complete Mitochondrial Genome Sequences, 2013, https://journals.plos.org/plosone/article?id=10.1371/journal.pone.0054360 [dostęp:_25.05.2019]; i inni.

14 H. Łowmiański, Początki Polski, Warszawa, PWN, 1963.

15 K. Moszyński, Badania nad pochodzeniem i pierwotna kultura Stowian, Kraków, Rozprawy PAU, t. LXII, nr 2, 1925.

${ }^{16}$ Idem, Pierwotny zasiag języka prasłowiańskiego, Wrocław, Ossolineum, 1957. 
Dopiero w kronikach Prokopiusza z Cezarei (lata 30. VI w.) i Jordanesa (ok. 551 r. n.e.) pojawia się określenie Sklavenoi, które można bez większych wątpliwości wiązać ze Słowianami. Dzięki nim wiemy, że był to lud od dłuższego czasu już zasiedziały nad Dunajem oraz na północ od tej rzeki ${ }^{17}$. Więcej szczegółów na temat osadnictwa Słowian dostarcza Jordanes, choć jego dzieło Getica (De origine actibusque Getarum) jest tylko streszczeniem wcześniejszego - niestety zaginionego - opracowania autorstwa Kasjodora. Dzięki Jordanesowi dowiadujemy się, że lud Sklawenów (Słowian) jest jednym z dwóch, obok Antów, odłamów Wenedów. Według Jordanesa Wenedowie mieli zaś zamieszkiwać tereny wzdłuż północnego (lewego) skłonu Karpat (nazywanych przez niego Alpami), od źródeł Wisły w kierunku wschodnim. Osadnictwo Sklawenów na południu rozciągało się od jeziora Mursjańskiego (być może podmokłe ujście Cisy do Dunaju) i miasta Noviodunum (prawdopodobnie chodzi o ośrodek zlokalizowany w pobliżu ujścia Dunaju), na północy po górną Wisłę i Dniestr, natomiast Antów między Dniestrem a Dnieprem ${ }^{18}$.

Zdaniem żyjącego w VII lub VIII w. Geografa Raweńskiego Słowianie mieli natomiast wywodzić się ze Scytii, z obszaru, „skąd wzięły początek pokolenia Sklawinów"19. W owych czasach pod pojęciem Scytii kryła się cała północno-wschodnia, barbarzyńska Europa na wschód od Laby $^{20}$. Ojczyzna Słowian na mapie Geografa z Rawenny znajduje się zaś w VI sektorze, na północ od Panonii, pomiędzy Cisą (Tisia) a Łabą (Albis), w południowej swej części nad rzeką o nazwie Flautasis, wpadającą do Dunaju, która swoim położeniem odpowiada Wagowi lub Morawie. Byłoby to więc nieco bardziej na zachód niż lokował Sklawenów Jordanes, w miejscu odpowiadającym mniej więcej Sarmacji Pomponiusza Meli. Zgodnie z przekazem Geografa Raweńskiego ojczyzna Słowian zajmowałaby więc tereny dzisiejszych Moraw, Słowacji i Polski, natomiast według Jordanesa znajdowałaby się na obszarze późniejszej Małopolski (górne dorzecze Wisły), Wołynia, Podola i Mołdawii (dorzecze Dniestru). Według Jordanesa obraz ten uzupełniali pokrewni Sklawenom Antowie, zamieszkujący rejon dzisiejszej południowej Ukrainy. Nie można jednak wykluczyć, że kronikarze mogli pominąć, szczególnie dalej na północy (dorzecze Wisły, dorzecze Dniepru), inne tereny osadnictwa Słowian czy ludów im pokrewnych (np. Wenedów).

${ }^{17}$ L.A. Tyszkiewicz, Słowianie i Awarowie. Organizacja plemienna Słowian, Wrocław, Ossolineum, 2009.

18 J. Strzelczyk, Od Prastowian..., op. cit.; L. Leciejewicz, Stowianie Zachodni..., op. cit.; M. Parczewski, Idzie nowe..., op. cit.

${ }_{19}$ H. Łowmiański, Scytia, [w:] Stownik starożytności słowiańskich, t. V, Wrocław, Ossolineum, 1975, ss. 101-119.

${ }^{20}$ J. Nalepa, O pierwotnych siedzibach ..., op. cit.; H. Łowmiański, Scytia, op. cit. 
Gdyby za Jordanesem Słowian utożsamić z Wenedami, tak jak to co najmniej od VII w. n.e. robili różni autorzy ${ }^{21}$ i ludy (Niemcy do dzisiaj nazywają niektóre grupy słowiańskie Wenden, a Finowie i Estończycy w podobny sposób - venäläiset, venelaste - Rosjan), to trudno jednak nie wspomnieć, że Wenetów/Wenedów wymieniają już wcześniejsi autorzy (oraz Jordanes w odniesieniu do wydarzeń z IV w.). Na początku naszej ery Pliniusz Starszy pisał, że Wenetowie zamieszkują ziemie do rzeki Wisły, co pokrywa się z relacją Jordanesa. Pliniusz nie precyzuje jednak, od której strony Wisła ogranicza Wenetów (a wraz z nimi także Sarmatów) ${ }^{22}$, co jest intrygujące, bo współczesny mu Pomponiusz Mela opisuje Sarmację jako kraj po zachodniej stronie Wisły ${ }^{23}$, a to Sarmacja właśnie, zdaniem wielu kronikarzy, miała być obszarem osadnictwa Wenetów (na późniejszej Tabuli Peutingerianie pojawia się nawet nazwa Venadisarmatea). Około roku 100 n.e. Tacyt sytuuje Wenetów miedzy Fennami (ludami łowieckimi strefy leśnej północnej Europy) a Peucynami (Bastarnami), a wiec gdzieś między Karpatami a regionem wschodniobałtyckim, czyli na podobnym obszarze (w sąsiedztwie Wisły). Nieco tylko później (połowa II w. n.e.) Klaudiusz Ptolemeusz umieszcza Wenetów w Sarmacji (według niego, inaczej niż u Pomponiusza Meli, rozpościerającej się na wschód od Wisły, co jednak skłania do przypuszczeń, że Wenetowie mogliby mieszkać także na zachód od tej rzeki) i nazywa wielkim ludem, choć przechodząc do szczegółów, wskazuje miejsce zamieszkania ludu o tej nazwie nad Zatoką Wenedyjską (Morzem Bałtyckim?), między Gotami a Galindami (Bałtami) - a więc na niewielkim obszarze. Można przypuszczać, że w tym ostatnim przypadku chodzi o jakiś odosobniony (odcięty przez Gotów od pobratymców) odłam Wenetów, podczas gdy reszta „wielkiego ludu" kryłaby się pod nazwami mniejszych, wymienionych przez Ptolemeusza i sąsiadujących ze sobą plemion: Sulonowie (Bulanowie), Frugundinowie, Koistobokowie, Igyllionowie, Gewinowie, Bodinowie, Stawanowie, Awarinowie albo też innych plemion, umieszczonych przez kronikarza we wschodniej Germanii (a zatem w Sarmacji Pomponiusza Meli). Ich osadnictwo pasowałoby do umiejscowienia Wenetów zarówno przez poprzednich (Pliniusz, Tacyt), jak i późniejszych kronikarzy (Jordanes) - czyli nad Wisłą.

Natomiast Tabula Peutingeriana (prawdopodobnie z połowy IV w.) umieszcza Wenetów zarówno nad morzem (Bałtykiem?) na północy (jako Venadisarmatea), a więc prawdopodobnie tam gdzie Ptolemeusz, jak i u ujścia Dunaju. Jeżeli w obu

${ }^{21}$ E. Mühle, Die Slaven im Mittelalter, Berlin, De Gruyter, 2016.

22 J. Kolendo, Wenetowie w Europie środkowej $i$ wschodniej: lokalizacja i rzeczywistość etniczna, „Przegląd Historyczny” 1984, nr 4, ss. 637-653.

${ }^{23}$ L.A. Tyszkiewicz, Stowianie w historiografii antycznej do połowy VI wieku, Wrocław, Wydawnictwo Uniwersytetu Wrocławskiego, 1990. 
miejscach mowa jest o tym samym ludzie, to prawdopodobnie należałoby się go również spodziewać pomiędzy nimi, czyli na tzw. pomoście bałtycko-czarnomorskim (dorzecza Wisły, Prypeci, Dniestru, Bohu). Dzięki Jordanesowi wiemy również, że mniej więcej w tym samym czasie (druga połowa IV w.) gdzieś w tych rejonach toczyły się walki pomiędzy Ostrogotami a Wenetami, którzy wprawdzie byli kiepscy do oręża, lecz znaczni swą liczebnością ${ }^{24}$. Pozostaje jednak wątpliwość, czy wcześniejsi Wenetowie to ci sami, co Wenedowie-Sklawenowie Jordanesa z VI w., czy tylko lud, którego imię zostało przez późniejszych kronikarzy przeniesione na Słowian. Nie możemy być nawet pewni, czy sam Jordanes, pisząc o Wenedach w IV i w VI wieku, rzeczywiście opisuje ten sam lud. Jeżeli ten sam (a pisarz mógł mieć jakąś wiedzę w tej sprawie), to można by Wenetów z Tabuli Peutingeriany, mieszkających w tym samym czasie nad Bałtykiem, również utożsamić z Wenetami Jordanesa. Stanowiłoby to świadectwo, że Wenetowie utożsamiani ze Sklawenami, już w IV w. zamieszkiwali dorzecze dolnej Wisły.

Niezależnie od tego należy zauważyć, że w tej części Europy nazwa Wenedowie/Wenetowie pojawia się już w początkach naszej ery i w zasadzie na jednym, dość szerokim obszarze: między Morzem Bałtyckim, Wisłą, Karpatami, Morzem Czarnym i Dnieprem, przy czym dopiero w VI w. może być bezspornie wiązana z ludami słowiańskimi: Sklawenami (Słowianami) i Antami. Trudno więc zgodzić się z opinią Andrzeja Kokowskiego, że „Wenedowie są dość dowolnie lokalizowani w różnych częściach Europy, w różnym czasie"25, tym bardziej, że autor sam nieco dalej podkreśla, że ,należało się już dawno pożegnać z przekonaniem, że Rzymianie i Grecy słabo orientowali się w sytuacji etnicznej na północ od Karpat”26. W związku z tym należy więc podkreślić konsekwencję umieszczania etnonimu Wenetowie/ Wenedowie na zbliżonym pod względem zasięgu obszarze od początków naszej ery i łączenie go w VI w. oraz później (w zasadzie do dzisiaj w przypadku etnonimów Wenden czy Venelaste) ze Słowianami.

\section{Archeologia}

Ważny wkład w badaniach nad wczesną Słowiańszczyzną jest zasługą archeologów. Uznając przekaz Jordanesa za wiarygodny, należałoby przyjąć, że Słowian z czasów pierwszych wzmianek o nich (VI w.) należy kojarzyć z kulturą prasko-korczakowską, która rozwijała się na obszarze zasiedlonym przez Sklawenów. Na tej samej

\footnotetext{
${ }^{24}$ M. Parczewski, Idzie nowe..., op. cit., ss. 59-65.

25 A. Kokowski, Starożytna Polska..., op. cit.

${ }^{26}$ Ibidem.
} 
zasadzie z Antami należałoby wiązać archeologiczną kulturę pieńkowską. Z uwagi na nazwę za główną grupę słowiańską należy przede wszystkim uznać Sklawenów (czyli niejako Słowian właściwych), stąd istotne w kwestii ich pochodzenia może być ustalenie genezy kultury prasko-korczakowskiej. W tej jednak sprawie badacze sugerują bardzo odmienne hipotezy. Niektórzy widzą w tej kulturze kontynuację kultury zarubinieckiej ${ }^{27}$, przeworskiej ${ }^{28}$, czernichowskiej ${ }^{29}$, kijowskiej ${ }^{30}$. Inni podkreślają nawet jej związki z kulturą imieńkowską znad Wołgi i Kamy, czyli z kulturą terenu, gdzie według Ptolemeusza mieszkali Suowenoi, a według arabskich pisarzy lud Saqaliba we wczesnym średniowieczu ${ }^{31}$.

Część badaczy uważa, że z uwagi na ceramikę kultura praska najwięcej nawiązań ma właśnie do kultury imieńkowskiej, u której, choć powstałej daleko na wschodzie, dostrzegają jednocześnie silne wpływy zarówno kultury zarubinieckiej, jak i przeworskiej $^{32}$. Nie można w tym kontekście nie zauważyć, że kultura korczakowsko-praska ujawniła się pomiędzy Karpatami a Prypecią, a wiec na przestrzeni, gdzie na kulturę zarubiniecką nałożyła się najpierw kultura przeworska, a później czernichowska. Mogłoby to sugerować, że kultura prasko-korczakowska narodziła się w wyniku interakcji pomiędzy kulturami przeworską, zarubiniecką i czernichowską ${ }^{33}$.

Nie oznacza to oczywiście, że z przodkami Słowian należy utożsamiać jedynie Sklawenów, nosicieli kultury prasko-korczakowskiej. Obszar wołyńsko-podolsko-małopolski mógł być epicentrum krystalizacji nowej kultury i związanej z nią nazwy (Sklawenowie-Słowianie), która następnie mogła przenosić się na ludy pokrewne jej pod względem kulturowym. W przypadku ziem polskich dzięki tzw. badaniom autostradowym odkrywane są ostatnio przejawy kontynuacji osadnictwa post-przeworskiego, a także symptomy uproszczania form kulturowych w kierunku bliskim stylowi kultury praskiej ${ }^{34}$. Być może takim uproszczeniem, wynikającym z regresu

27 Г.С. Ле́бедев, Вернемся к началу, „Знание - сила”, 10, 1986, ss. 17-19.

${ }^{28}$ L. Leciejewicz, Stowianie Zachodni..., op. cit.

${ }_{29}$ В.В. Седов, Этногенез ранних Славян, „Вестник Российской Академии Наук”, 73, 7, 2003, ss. $594-605$.

${ }_{30}$ Е.В. Максимов, Миграџии в жизни древних Славян, [w:] Славяне и Русь (В зарубежной историографии), Киев, Наукова думка, 1990, ss. 5-11; М. Parczewski, Idzie nowe..., op. cit.

${ }^{31}$ Г.И. Матвеева, Некоторые итоги изучения именьковской культуры, [w:] Этногенез и этнокультурные контакты славян, Труды VI Международного конгресса славянской археологии. Т. 3. Москва, Наука, 1997, ss. 206-217; М.И. Жих, Ранние славяне в Среднем Поволжье (по материалам письменных источников), СПб-Казань, Вестфалика, 2011, 90 ss.

32 Г.И. Матвеева, Среднее Поволжье в IV-VII вв.: Именьковская культура, Самара, Самарский университет, 2004.

${ }^{33}$ В.Д. Баран, Славяне в середине I тысячелетия н.э., [w:] Б.А. Рыбаков (red.), Проблемы этногенеза славян, Киев, Наукова думка, 1978, ss. 5-37.

34 T. Makiewicz, $W$ sprawie aktualnego stanu..., op. cit.; Z. Kurnatowska, Nowe spojrzenie na genezę ceramiki wczesnośredniowiecznej, „Archeologia Polski”, t. LIII, z. 1, 2008, ss. 73-80. 
społeczno-gospodarczego i politycznego, tłumaczyć należy także genezę samej kultury prasko-korczakowskiej. Duża część badaczy związki pomiędzy wymienionymi kulturami dostrzega od dawna, a powiązania te mogły ułatwić rozprzestrzenianie się słowiańskiej kultury, języka i tożsamości.

Wielu badaczy zauważa, że kultura pomorska z dorzecza Wisły i Odry mogła mieć istotny wpływ na rozwój kultury zarubinieckiej ${ }^{35}$, a w rejonie kultury pomorskiej wyrosły kultury: przeworska i wielbarska ${ }^{36}$, zaś ta ostatnia łączona jest z czernichowską. Wszystko to działo się na obszarze dawnego horyzontu kultury trzcinieckiej, która wyrosła z tradycji kultury ceramiki sznurowej, utożsamianej z przodkami ludów północnej grupy języków indoeuropejskich (germańskich, słowiańskich i bałtyckich) ${ }^{37}$, których centralną grupę (argumenty językoznawców) tworzyć musieli Prasłowianie.

Na marginesie można również zaznaczyć, że według części badaczy z kulturą ceramiki sznurowej związana była także kultura Sintaszta-Pietrowka na Uralu, która identyfikowana jest z rozwojem języków indoirańskich. Potwierdzają to badania kopalnego DNA ${ }^{38}$. Kultura ceramiki sznurowej mogłaby więc mieć istotne znaczenie dla rozwoju jeszcze większego zespołu ludów posługujących się dialektami zaliczanymi do północno-wschodniej grupy języków indoeuropejskich (od germańskich przez bałtosłowiańskie po indoirańskie). Sugerują to również argumenty niektórych językoznawców, podkreślających w szczególności bliskie związki grupy indoirańskiej z bałtosłowiańską ${ }^{39}$, oraz struktura udziałów poszczególnych linii genealogicznych, związana ze znacznym odsetkiem linii R1a u dzisiejszych użytkowników tych języków ${ }^{40}$.

Za sprawą Kazimierza Godłowskiego ${ }^{41}$ dominuje przekonanie o allochtonicznym charakterze Słowian na ziemiach dzisiejszej Polski. Odrzucił on możliwość wiązania

35 В.В. Седов, Происхождение и ранняя история славян, Москва, Наука, 1979.

36 J. Strzelczyk, Goci. Rzeczywistość i legenda, Poznań, Wydawnictwo Poznańskie, 2015.

${ }_{77}$ D.W. Anthony, The Horse, the Wheel, and Language: How Bronze-Age riders from the Eurasian steppes shaped the modern world, Princeton, Princeton University Press, 2007.

${ }_{38}$ M. Allentoft et al., Population genomics of Bronze Age Eurasia, „Nature” 2015, nr 522 (7555), ss. 167-172; V.M. Narasimhan, The Genomic Formation of South and Central Asia, 2018, https://www. biorxiv.org/content/early/2018/03/31/292581.full.pdf [dostęp: 25.05.2019].

${ }^{39}$ D. Ringe, T. Warnow, A. Taylor, Indo-European and Computational Cladistics, „Transactions of the Philological Society" 2002, 100, 1, ss. 59-129; S. Starostin, Indo-European glottochronology and homeland, Paper presented at the Prehistoric Chronology Workshop, Santa Fe Institute, March 1-5, 2004; V. Blažek, From August Schleicher to Sergei Starostin. On the development of the tree-diagram models of the Indo-European languages, „Journal of Indo-European Studies”, 35, 1, 2007, ss. 82-109; Z. Gołąb, O pochodzeniu Słowian w świetle faktów językowych, Kraków, Universitas, 2004.

${ }^{40}$ P.A. Underhill et al., The phylogenetic and geographic structure of Y-chromosome haplogroup Rla, „European Journal of Human Genetics”, 23, 1, 2014, ss. 124-131.

${ }^{41}$ K. Godłowski, Pierwotne siedziby Stowian..., op. cit. 
Słowian w kulturą przeworską, którą przypisywał ludom germańskim (Wandalom). Jego zdaniem Germanowie opuścili dorzecze Wisły i Odry i dopiero na tym pozostawionym przez nich obszarze zaczęli osiedlać się słowiańscy przybysze ze wschodu. Niemniej pojawiają się nowe dowody świadczące o ciągłości osadniczej w dorzeczu Wisły i Odry między późnym okresem starożytności a wczesnym średniowieczem. W dużych centrach osadniczych na Kujawach czy nad środkową Prosną zlokalizowano pierwsze materiały wskazujące na kontynuację osadnictwa poprzeworskiego jeszcze w VI, a nawet i w początkach VII wieku, podobnie w okolicach Rogoźna ${ }^{42}$. Społeczności je zamieszkujące musiały zatem nawiązywać kontakty z ludnością kultury praskiej. Innymi słowy, udało się stwierdzić, iż schyłek starożytności i początki wczesnego średniowiecza na niektórych osadach o charakterze centralnym nakładały się na siebie ${ }^{43}$. Na podobne tendencje zwracają uwagę także inne badania ${ }^{44}$.

Ciągłość osadnictwa wydają się również potwierdzać analizy porównawcze cech morfometrycznych szczątków mieszkańców dorzecza Wisły i Odry z czasów starożytności i średniowiecza ${ }^{45}$. To samo sugerują badania kopalnego tDNA $^{46}$ czy też analiza pojedynczych próbek kopalnego Y-DNA ${ }^{47}$.

Niemniej zestawiając źródła pisane z materiałami archeologicznymi pewni możemy być jedynie tego, że słowiański charakter miała kultura prasko-korczakowska (Sklawenowie, a więc niewątpliwie Słowianie) i ewentualnie pieńkowska (Antowie). Nie można jednak wykluczyć, że jakieś plemiona słowiańskie (lub bliskie słowiańskim) umknęły uwadze dawnych kronikarzy, a mogły one reprezentować zupełnie odmienne kultury niż prasko-korczakowska. Część ludów prasłowiańskich mogła rozwijać się w kręgu kultury przeworskiej lub wielbarskiej i dopiero po pojawieniu się kultury korczakowsko-praskiej ulec jej oddziaływaniu. Badacze już dawno zwrócili uwagę, że kultur archeologicznych nie można utożsamiać z grupami etnicznymi czy językowymi (walka z tzw. kossinizmem w interpretacjach odkryć archeologicz-

42 S. Zdziebłowski, Nowe dowody na obecność ludzi na terenach Polski w późnej starożytności, 2018, http://scienceinpoland.pap.pl/aktualnosci/news\%2C31468\%2Cnowe-dowody-na-obecnosc-ludzi-na-terenach-polski-w-poznej-starozytnosci.html [dostęp; 25.05.2019].

${ }^{43}$ A. Bursche, Wstep. Barbarzyńskie tsunami, [w:] A. Bursche (red.), Barbarzyńskie tsunami..., op. cit., ss. 7-15.

${ }_{44}$ T. Makiewicz, W sprawie aktualnego stanu ..., op. cit.; Z. Kurnatowska, Nowe spojrzenie..., op. cit.

45 J. Piontek, B. Iwanek, S. Segeda, Antropologia o pochodzeniu..., op. cit.

${ }_{46}$ M. Mielnik-Sikorska et al., The History of Slavs..., op. cit.

${ }^{47} \mathrm{Na}$ ziemiach Polskich (Gustorzyn na Kujawach), a nawet dalej na zachód (Halberstadt-Sonntagsfeld), w warstwach przypisywanych epoce brązu, odnajdywane są szczątki osobników należących do linii genealogicznej R1a, o mutacjach występujących u ludów słowiańskich (Z280) (W. Haak et al., Massive migration from the steppe was a source for Indo-European languages in Europe, "Nature” 2015, nr 522(7555), ss. 207-211; D. Wesołowski (Davidski), Rla-Z280 from Early Bronze Age Northern Poland, 2017, http://eurogenes.blogspot.com/2017/01/r1a-z280-from-early-bronze-age-northern. html [dostęp: 25.05.2019]). 
nych). Michał Parczewski zauważa również, że nawet grupy językowej nie powinno się utożsamiać z etnosem, gdyż ten ostatni to coś więcej niż tylko posługiwanie się określonym językiem ${ }^{48}$.

Należy również zauważyć, że załamanie osadnictwa i regres gospodarczy w dorzeczu Wisły i Odry nie musiał być wywołany wędrówkami ludów, lecz razem z nimi mógł być spowodowany bardziej zasadniczymi przyczynami. Istnieje szereg przesłanek sugerujących, że wśród czynników, które spowodowały załamanie się osadnictwa okresu wpływów rzymskich w wielu rejonach Europy były zmiany klimatyczne. Silne susze w III w. i w pierwszej połowie VI w. były powodem spadku produkcji rolnej, a w konsekwencji okresów głodu. W VI w. wystąpiły okresy silnego ochłodzenia $\mathrm{w}$ rezultacie potężnych erupcji wulkanicznych w latach 536, 540 i 547, na które nakładało się przypadające w tym czasie minimum aktywności słońca. Rozpowszechniająca się w latach 541-543 epidemia dżumy, tzw. plaga justyniańska, i jej nawroty w następnych latach, miały dalsze konsekwencje demograficzne i gospodarcze. $Z$ kolei poprawa i stabilizacja klimatu w połowie VII w. sprzyjała budowie nowego ładu politycznego w Europie i rozwojowi osadnictwa na wcześniej wyludnionych terenach, $w$ tym na obszarze Polski ${ }^{49}$. Z tego powodu zmniejszenie intensywności osadnictwa i regres społeczno-gospodarczy w dorzeczu Wisły i Odry można by wytłumaczyć jedynie wpływem wspomnianych klęsk. Gdy jednak uwzględnimy niewątpliwy odpływ pewnych, być może zasadniczych dla porządku politycznego i społeczno-gospodarczego okresu rzymskiego, grup ludności (Wandalów, Gotów, Burgundów), nadejście zapaści kulturowej, przy zachowaniu części dotychczasowego osadnictwa (germańskiego, prasłowiańskiego, wenetyjskiego), wydaje się tym bardziej zrozumiałe. Być może już w niedługim czasie pojawily się nowe elity, przybywające ze wschodu lub z południa (Panonia).

Właśnie w strefie leśnej i leśno-stepowej na Ukrainie koncentrują się najwcześniejsze, to jest datowane w sposób pewny na $\mathrm{V}$ w., zespoły archeologiczne, które można bezspornie przypisać kulturom słowiańskim. W Polsce nie znaleziono do tej pory ani jednego równie archaicznego kompleksu. Najstarsze ślady osadnictwa nad górną i środkową Wisłą, należące do tzw. kultury praskiej, rejestrujemy najwcześniej około przełomu V i VI w. ${ }^{50}$ To może wskazywać, że te nowe elity (oraz być może jakieś towarzyszące im szersze masy ludności) przybyły wtedy z tamtego

${ }^{48}$ M. Parczewski, Współczesne poglądy w sprawie etnogenezy oraz wielkiej wędrówki Stowian, [w:] M. Salamon i J. Strzelczyk (red.), Wędrówka i etnogeneza w starożytności i w średniowieczu, Kraków, Historia Iagellonica, 2010, ss. 221-230.

${ }^{49}$ M. Latałowa, Przyrodnicze ślady przemian osadniczych między Odra a Wisła w I tysiacleciu po Chr., [w:] A. Bursche (red.), Barbarzyńskie tsunami ..., op. cit., ss. 17-23.

${ }^{50}$ M. Parczewski, Idzie nowe..., op. cit. 
kierunku, choć może skierowały się początkowo na południe (Nestor lokuje kolebkę Słowian w Panonii $\left.{ }^{51}\right)$.

\section{Językoznawstwo}

W badaniach i dyskusji nad kolebką Słowian biorą udział także językoznawcy. Ostatnio ugruntowało się przekonanie dotyczące jednorodności języka słowiańskiego, utrzymującej się do połowy I tys. n.e. Oznaczać by to musiało, że tuż przed ekspansją obszar osiedlenia użytkowników języka słowiańskiego nie mógł być zbyt duży. Inaczej język słowiański byłby znacznie bardziej zróżnicowany ${ }^{52}$.

Istotne znaczenie w kwestii miejsca krystalizacji dialektu słowiańskiego mają badania nad hydronimią oraz obserwacje związków pomiędzy językami. Języki słowiańskie wykazują największe pokrewieństwo z językami bałtyckimi i być może wywodzą się ze wspólnego pradialektu. W porównaniu z nimi języki słowiańskie wykazują jednak znacznie mniej związków z językami ugrofińskimi, natomiast znacznie więcej z germańskimi i irańskimi. Interesujące jest, że związki z językami germańskimi dotyczą przede wszystkim dialektów zachodnio- (przodków niemieckiego, niderlandzkiego, angielskiego), a nie wschodniogermańskich (gockiego, wandalskiego) $)^{53}$. Wskazywać by to mogło, że dialekt słowiański kształtował się na południe od dialektów bałtyckich, w szerokiej strefie rozciągającej się od siedzib przodków ludów zachodniogermańskich na zachodzie po siedziby ludów irańskich na wschodzie. Wyklucza to więc obszar dorzecza górnego Dniepru i obszary na wschód od niego jako strefę formowania się języka słowiańskiego, co zresztą potwierdzają argumenty toponimiczne ${ }^{54}$.

Językoznawcy starają się szukać słowiańskiej kolebki, analizując hydronimię, najbardziej konserwatywną warstwę toponimii. Trudno jednak znaleźć bezsporną i dawną hydronimię pochodzenia słowiańskiego. Według Zbigniewa Babika można jednak wyodrębnić obszary, których toponimia nie sprzeciwia się tezie o lokalizacji na nich nosicieli języka prasłowiańskiego u schyłku starożytności. Jednym z takich rejonów może być niewątpliwie Mazowsze (zwłaszcza bliższe) oraz Polska środkowa (?) i Małopolska, w przeciwieństwie do Śląska, a chyba też do niewyodrębniających się wyraźnie Wielkopolski i Pomorza. Zdaniem tego badacza nazewnic-

${ }^{51}$ F. Sielicki (przeł. i oprac.), Nestor - Powieść minionych lat, Wrocław, Ossolineum, 1999.

${ }^{52}$ H. Popowska-Taborska, Wczesne dzieje Stowian w świetle ich języka, Wrocław, Kraków, Ossolineum, 1991; Z. Babik, Wspólnota językowa prasłowiańska, [w:] Przeszłość społeczna. Próba konceptualizacji. S. Tabaczyński (red.), Poznań, Wydawnictwo Poznańskie, 2012, ss. 838-851.

${ }^{53}$ Ibidem.

${ }^{54}$ Ibidem. 
two dorzeczy Wisły i Odry charakteryzuje się niższym niż obszary na wschodzie udziałem elementów „substratowych” (przedsłowiańskich) i największą częstością występowania elementów rodzimych (słowiańskich) w makrohydronimi ${ }^{55}$. Należy również uwzględnić obszar dzisiejszej zachodniej Ukrainy, a więc Wołyń, Podole i zachodnią Kijowszczyznę (po środkowy Dniepr) ${ }^{56}$. Na podobny obszar zwracał uwagę już Tadeusz Lehr-Spławiński ${ }^{57}$. Odpowiadałoby to mniej więcej usytuowania Słowian z czasów pierwszych wzmianek o nich (Wenedowie-Sklawenowie Jordanesa), jak również wcześniejszych wzmianek o Wenetach (Pliniusz Starszy, Ptolemeusz, Tacyt).

Wobec znaczenia kultury praskiej w rozprzestrzenianiu się plemion słowiańskich można domyślać się, że ten dialekt i upowszechniająca go grupa swoją niezbyt rozległą kolebkę posiadała właśnie na obszarze kształtowania się kultury prasko-korczakowskiej. Być może dla zamieszkującej ten teren grupy powstało, pod wpływem okoliczności związanych z jakimś procesem etnicznym (być może odpowiadającym formowaniem się kultury prasko-korczakowskiej), określenie Słowianie (Sklawenowie) - zapisane po raz pierwszy przez Jordanesa - oraz uformował się charakterystyczny dla nich język.

W tym kontekście ciekawa wydaje się koncepcja Krzysztofa Fokta ${ }^{58}$, który zgodnie z postulatem Henryka Łowmiańskiego sytuuje na obszarze Małopolski i Wołynia zaplecze osadnicze dla rozprzestrzeniania się słowiańskich plemion Serbów, Chorwatów i Dudlebów. Według K. Fokta te trzy plemiona były głównymi koalicjantami Awarów, pośredniczącymi w zarządzaniu masami ludów słowiańskich znajdujących się pod awarską władzą. Elity tych plemion mogły być, jego zdaniem, od pewnego momentu również pochodzenia awarskiego, co wyjaśniałoby znaczenie, jakie uzyskały one w awarskiej organizacji politycznej. Tymi okolicznościami autor ten thumaczy późniejsze rozprzestrzenienie miejsc osadnictwa poszczególnych części tych trzech plemion na szerokim obszarze otaczającym łukiem Kotlinę Panońską: od Wołynia przez południową Polskę, Czechy i Dalmację do południowej Panonii. Można by tę koncepcję wykorzystać dla rozwinięcia hipotezy Z. Babika, stawiającego przypuszczenie, że za rozpowszechnienie się dialektu słowiańskiego odpowiedzialna była grupa wojowników, propagując na obszarze całej Słowiańszczyzny pewien zunifikowany standard językowy ${ }^{59}$. Pierwotnej siedziby tych trzech plemion należy więc szukać w dorzeczu górnej Wisły, górnego Dniestru, Bugu i południowych dopływów

55 Z. Babik, Wspólnota językowa..., op. cit.

${ }^{56}$ Idem, Najstarsza warstwa..., op. cit.; Idem, Wspólnota językowa..., op. cit.

${ }^{57}$ L. Moszyński. Wstęp do filologii stowiańskiej, Warszawa, PWN, 2006.

${ }^{58}$ K. Fokt, Śladami etnicznej stratygrafii, czyli u źródeł zachodniej połowy Stowiańszczyzny, [w:] M. Salamon i J. Strzelczyk (red.), Wędrówka i etnogeneza ..., op. cit., ss. 269-289.

${ }^{59}$ Z. Babik, Wspólnota językowa..., op. cit. 
Prypeci. To ich mógł Jordanes nazywać Sklawenami, gdyż według niego dzielili się oni na mniejsze plemiona („A choć ich imiona zmienne są teraz”), ale niestety nie wymienił ich nazw. Sklawenowie, przenosząc się do Kotliny Panońskiej, znaleźli się pod zwierzchnictwem Awarów i stali się ich głównymi, uprzywilejowanymi poddanymi. Później natomiast przemieścili się w różne części Słowiańszczyzny. Stąd być może wzięło się przekonanie, wyrażone przez Nestora, że Słowianie wywodzą się z Panonii ${ }^{60}$. Kto wie, czy na wschodzie słowiańskiego osadnictwa podobnej roli nie odegrali Siewierzanie i Dregowicze, których nazwy powtarzają się tak na północy (na Rusi), jak i we wschodniej części Bałkanów (Sewercy, Draguwici) ${ }^{61}$ ? Nie trzeba od razu przyjmować koncepcji Florina Curty, sugerującego, że etnogeneza Słowian nastąpiła w dolinie Dunaju w wyniku kontaktów z Bizantyjczykami ${ }^{62}$, ale można założyć, że naddunajski epizod Słowian miał istotne znaczenie dla umocnienia ich odrębnych tradycji i dalszych ekspansji w różnych kierunkach.

Badania językoznawców sugerują również, że w dorzeczu Wisły i Odry nie mogła nigdy powstać pustka osadnicza. Świadczą o tym przedsłowiańskie nazwy rzek i innych elementów topograficznych ${ }^{63}$. Słowianie musieli przejąć je bardzo wcześnie, żyjąc tu jeszcze przed okresem wędrówek ludów lub w wyniku wędrówki ludów, mieszając się z autochtonami, podobnie jak na Bałkanach.

\section{Genealogia genetyczna}

Ostatnio istotną rolę zaczęły odgrywać badania genetyczne. Posługuje się nimi m.in. genealogia genetyczna, badająca społeczności ludzkie z punktu widzenia linii genealogicznych, czyli męskich (Y-DNA) i żeńskich (mtDNA) haplogrup i haplotypów. Są to dziedziczone z pokolenie na pokolenie układy markerów genetycznych, zajmujące niewielki fragment naszego DNA. Syn dziedziczy go po ojcu, a córka po matce. Podobnie jest w następnych pokoleniach. Dzięki temu możemy obserwować ciągłość poszczególnych linii genealogicznych ${ }^{64}$. Z tego punktu widzenia haplogrupy pełnią rolę naturalnych nazwisk. O ile jednak prawdziwe nazwiska powstały stosunkowo niedawno i bardzo często ulegają zmianom w różnych okolicznościach, to

${ }^{60}$ F. Sielicki (przeł. i oprac.), Nestor..., op. cit.

${ }^{61}$ S. Zakrzewski, Opis grodów i terytoriów z pótnocnej strony Dunaju czyli tzw. Geograf Bawarski, Lwów, Towarzystwo dla Popierania Nauki Polskiej, 1917

${ }^{62}$ F. Curta, The Making of the Slavs. History and Archaeology of the Lower Danube Region, c. 500-700, Cambridge, Cambridge University Press, 2001.

${ }^{63}$ Z. Babik, Najstarsza warstwa..., op. cit.

${ }^{64}$ L. Handschuh et al., W poszukiwaniu Piastów, „Opolskie Studia Administracyjno-Prawne”, XIV, 4(2), 2016, ss. 63-77. 
nasze genetyczne nazwiska istnieją od tysiącleci i nie można ich zmienić. To bardzo cenna właściwość, pomagająca badać zjawiska dotyczące pojedynczych rodzin i całych ludzkich zbiorowości ${ }^{65}$.

Niektóre linie genetyczno-genealogiczne częściej występują w jednych zbiorowościach ludzkich, inne w innych. W naszych rozważaniach proponuję ograniczyć się do haplogrupy Y-DNA, która, tak jak tradycyjne nazwisko w społeczeństwach europejskich, jest dziedziczona w linii męskiej. Pod tym względem zauważalny jest wyraźny podział w ramach Europy. Mężczyźni w Europie Zachodniej są w zdecydowanej większości przedstawicielami linii genealogicznej R1b, podczas gdy w Europie Wschodniej wyraźnie dominuje linia Rla. Nosiciele tych dwóch „nazwisk” posiadali co prawda wspólnego przodka (nosiciela „nazwiska” R1), ale było to jakieś 20-30 tys. lat temu ${ }^{66}$. Udział mniej licznych „,nazwisk” tego typu (np. haplogrupy I2, I1, G2a, J, E, N) też jest inny w obu częściach Europy ${ }^{67}$. Świadczy to o odrębności ruchów migracyjnych w przeszłości, o odmiennym pochodzeniu i izolacji pomiędzy wschodem i zachodem naszej części świata.

Dochodzą do tego różnice na mniejszą skalę. Okazuje się bowiem, że przedstawiciele linii R1a przeważają jedynie w północnej części Europy Wschodniej, najwyższy odsetek przyjmując wśród następujących słowiańskich grup etnicznych: Serbowie łużyccy $(64 \%)^{68}$, Polacy $(57 \%)^{69}$, Białorusini (53\%), Rosjanie (47\%), Słowacy (45\%), Ukraińcy (44\%), Czesi $(38 \%)^{70}$. Dość zbliżony udział przyjmują również u dwóch narodów bałtyckich: Litwini $(44 \%)^{71}$, Łotysze $(40 \%)^{72}$ oraz

${ }^{65}$ B. Sykes, Adam's Curse: A Future Without Men, Bantam, London-New York, 2003; D. Reich, Who We Are and How We Got Here, Oxford, Oxford University Press, 2018.

${ }^{66}$ P. A. Underhill et al., The phylogenetic..., op. cit.

${ }^{67}$ A. Kushniarevich et al., Genetic Heritage of the Balto-Slavic Speaking Populations: A Synthesis of Autosomal, Mitochondrial and Y-Chromosomal Data, „PLOS One”, 10(9), 2015, https://journals. plos.org/plosone/article?id=10.1371/journal.pone.0135820 [dostęp: 25.05.2019].

${ }^{68} \mathrm{~K}$. Rębała et al., Contemporary paternal genetic landscape of Polish and German populations: from early medieval Slavic expansion to post-World War II resettlements, „European Journal of Human Genetics", 21(4), 2013, ss. 415-422.

${ }^{69}$ M. Kayser et al., Significant genetic differentiation between Poland and Germany follows present-day political borders, as revealed by Y-chromosome analysis, „Human Genetics”, 117(5), 2005, ss. 428-443;

${ }^{70}$ A. Kushniarevich et al., Genetic Heritage..., op. cit.; A. Kushniarevich et al., Uniparental genetic heritage of Belarusians: encounter of rare Middle Eastern matrilineages with a Central European mitochondrial DNA pool, „PLOS One” 8, 2013, https://journals.plos.org/plosone/article?id=10.1371/ journal.pone.0066499 [dostęp: 25.05.2019].

${ }^{71}$ Ibidem; D. Kasperaviciūte et al., Y chromosome and mitochondrial DNA variation in Lithuanians, „Annals of Human Genetics”, 68, 2004, ss. 438-452.

${ }^{72}$ A. Kushniarevich et al., Genetic Heritage..., op. cit.; Pliss L. et al., Y-Chromosomal Lineages of Latvians in the Context of the Genetic Variation of the Eastern-Baltic Region, „Annals of Human Genetics", 79(6), 2015, ss. 418-430. 
u sąsiadujących ze Słowianami i Bałtami ludów fińskich: Estończycy (33-37\% $)^{73}$, Karelczycy $(40 \%)^{74}$, Mordwini $(20-40 \%)^{75}$, Maryjczycy $(30-50 \%)^{76}$. Wśród innych grup etnicznych jest ich już mniej, choć można spotkać interesujące niespodzianki. Dość dużo przedstawicieli linii R1a jest wśród Norwegów $(22 \%)^{77}$, a jeszcze więcej wśród Kirgizów $(47 \%)^{78}$. Tu pomocna okazuje się wiedza dotycząca zróżnicowania w obrębie poszczególnych haplogrup. Norwegowie linii R1a noszą bowiem w zdecydowanej większości mutację Z824, podczas gdy Kirgizi Z93. Tymczasem Słowianie, Bałtowie i wspomniane ludy fińskie noszą przede wszystkim mutacje Z280 i M458. Wszystkie osoby z tymi różnymi mutacjami w ramach R1a miały wspólnego przodka w linii męskiej, ale żył on co najmniej 5 tysięcy lat temu ${ }^{79}$. Pokazuje to odległe pokrewieństwo pomiędzy tymi ludami (poświadczone również badaniami językoznawczymi), sięgające zapewne początków kultury ceramiki sznurowej (badacze wskazują na przedstawicieli linii R1a, jako najliczniej występujących w społeczności tej kultury ${ }^{80}$ ), ale jednocześnie bardzo długi rozwój we wzajemnej izolacji, który pozwolił uformować się skupiskom odmiennych mutacji poszczególnych haplogrup Y-DNA (czyli niejako „przydomków” do naturalnych „nazwisk”).

Istotne jest, że dwie mutacje R1a, występujące głównie u Słowian, Bałtów i Finów, też okazują się nieproporcjonalnie rozpowszechnione w tych grupach. Na obszarach wskazywanych najczęściej jako kolebka Słowiańszczyzny (Polska i Ukraina) mutacje M458 i Z280 występują w podobnych proporcjach ${ }^{81}$. Tymczasem u Białorusinów i Rosjan, na obszarach pierwotnie bałtyjskich ${ }^{82}$ i fińskich ${ }^{83}$, zaznacza się wyraźna

73 P.A. Underhill et al.., The phylogenetic..., op. cit.; P. Malaspina et al., Analysis of Y-chromosome variation in modern populations at the European-Asian border, [w:] Ancient Interactions: east and west in Eurasia, K. Boyle (red.), „McDonald Institute for Archaeological Research Monographs”, Cambridge University, 2003, ss. 309-313.

74 P.A. Underhill et al., The phylogenetic..., op. cit.

${ }^{75}$ P. Malaspina et al., Analysis of Y-chromosome..., op. cit.; K. Tambets et al., The western and eastern roots of the Saami - the story of genetic "outliers" told by mitochondrial DNA and Y chromosomes, „American Journal of Human Genetics”, 74(4), 2004, ss. 661-682.

${ }^{76}$ Z.H. Rosser et al., Y-chromosomal diversity in Europe is clinal and influenced primarily by geography, rather than by language, „American Journal of Human Genetics”, 67(6), 2000, ss. 1526-1543; $\mathrm{K}$. Tambets et al., The western and eastern..., op. cit.

77 P.A. Underhill et al., The phylogenetic..., op. cit.

78 Ibidem.

79 Ł. Łapiński, Rla Clades, 2016, https://siliusradicum.pl/projekt-silesia/haplogrupy/haplogrupa-r1a/ [dostęp: 25.05.2019].

${ }^{80}$ M. Allentoft et al., Population genomics..., op. cit.

${ }^{81}$ A. Kushniarevich et al., Genetic Heritage..., op. cit.

82 Ł. Okulicz, Osadnictwo strefy wschodniobattyckiej w I tysiącleciu przed nasza era, Wrocław, Ossolineum, 1976.

83 Д.А. Мачинский, В.С. Кулешов, Северные народы середины IV - первой половины VI 8. в ,, Getica” Иордана, [w:] Л. і Г. Лебедев (red.), Восьмые чтения памяти Анны Мачинской, 2004, 
przewaga mutacji Z2804. Jeszcze większa jej przewaga wśród nosicieli „nazwiska” R1a występuje u Bałtów ${ }^{85}$ i ludów fińskich ${ }^{86}$. Pod wpływem tych spostrzeżeń nasuwa się przypuszczenie, że tak jak Z284 był pierwotnie charakterystyczny dla Praskandynawów, Z93 dla Prairańczyków, tak M458 dla Prasłowian, a Z280 dla Prabałtów. Każda z mutacji zdobywała przewagę w kształtujących się we wzajemnej izolacji, ale posiadających wspólnych przodków, odgałęzieniach ludów indoeuropejskich. Znaczący odsetek R1a z dominacją mutacji Z280 u ludów fińskich (a więc językowo nie indoeuropejskich, ale uralskich), tak jak występowanie linii genealogicznej Y-DNA N u Bałtów (ale liczniejszej wśród ludów fińskich), tłumaczyć by zaś należało sąsiedztwem i intensywnymi kontaktami między ludami bałtyckimi i fińskimi, co potwierdzają badania językoznawców ${ }^{87}$.

W podobny sposób musiało nastąpić wymieszanie linii genealogicznych M458 i Z280, które badacze uważają za związane z historycznymi ${ }^{88}$ i dzisiejszymi ludami słowiańskimi ${ }^{89}$. W tym kontekście pojawiają się wątpliwości, która z nich jest bardziej „prasłowiańska”. Ponieważ M458 stanowi znaczący odsetek R1a jedynie wśród ludów słowiańskich (Serbowie łużyccy - 88\%, Czesi - 75\%, Polacy - 48\%, Bułgarzy - 43\%, Słowacy - 35\%, Ukraińcy - 33\%, Białorusini - 29\%, Rosjanie $27 \%)^{90}$, nasuwa się przypuszczenie, że to właśnie duży odsetek tej mutacji był charakterystyczny dla pierwotnych Słowian (Prasłowian?). Z tego też powodu najbliższe genealogicznie pierwotnym Słowianom byłyby te dzisiejsze ludy słowiańskie, u których obserwujemy szczególnie duży odsetek R1a, przy jednoczesnym wysokim udziale M458 w ramach R1a. Są to raczej społeczności zachodniosłowiańskie: Serbowie łużyccy, Czesi, Polacy, Słowacy i ewentualnie jeszcze Ukraińcy.

ss. 26-72; А.К. Матвеев, К проблеме расселения летописной мери (рус.), „Известия Уральского государственного университета" 1997, 7, ss. 5-17.

${ }^{84}$ P.A. Underhill et al., The phylogenetic..., op. cit.; A. Kushniarevich et al., Genetic Heritage..., op. cit.; A. Kushniarevich, The Y chromosome R1A1A7 (M458) haplogroup of modern Belarusians and migrations of ancestors of Slavs on Belarus 'territory, „Russian Journal of Genetics: Applied Research", 2, 2, 2012, ss. 114-121.

${ }^{85}$ Pliss L. et al., Y-Chromosomal Lineages of Latvians in the Context of the Genetic Variation of the Eastern-Baltic Region, „Annals of Human Genetics” 2015, 79(6), ss. 418-430.

${ }^{86}$ P.A. Underhill et al., The phylogenetic..., op. cit.

${ }^{87}$ Z. Babik, Wspólnota językowa..., op. cit.

${ }^{88}$ P.A. Underhill et al., The phylogenetic..., op. cit.

89 M. Mielnik-Sikorska et al., Genetic data from Y chromosome STR and SNP loci in Ukrainian population, „Forensic Science International: Genetics” 7, 2013, ss. 200-203; A. Kushniarevich, The Y chromosome..., op. cit.

${ }^{90} \mathrm{~S}$. Karachanak et al., Y-chromosome diversity in modern Bulgarians: new clues about their ancestry, „PLOS One”, 8 (3), 2013, https://journals.plos.org/plosone/article?id=10.1371/journal. pone.0056779 [dostęp: 25.05.2019]; P.A. Underhill et al., The phylogenetic..., op. cit.; K. Rębała et al., Contemporary paternal..., op. cit.; A. Kushniarevich et al., Genetic Heritage..., op. cit. 
Nie można jednak wykluczyć, że z uwagi na bliskie pokrewieństwo Słowian i Bałtów mieli oni wspólną charakterystyczną haplogrupę - Z280, różnicując się dopiero na poziomie dalszych mutacji. Przedstawiciele linii genealogicznej M458 byliby natomiast ludnością obcą, wchłoniętą dopiero później przez Słowian (Prasłowian?). Wydaje się jednak, że wymieszanie przedstawicieli obu linii genealogicznych u bezpośrednich przodków Słowian musiało nastąpić jeszcze przed ekspansją słowiańską początków średniowiecza. Świadczy o tym obecność obu grup wśród dzisiejszych Słowian południowych. W zachodniej ich części (Słoweńcy, Chorwaci, Serbowie) wśród R1a wyraźnie, co prawda, przeważa Z280, ale we wschodniej (Bułgarzy) obie mutacje się równoważą ${ }^{91}$. Niemniej również na zachodzie Bałkanów można odnaleźć znaczące skupiska M458, na przykład w niektórych regionach Chorwacji (nawet do $67 \%$ całego R1a ${ }^{92}$ ).

Badacze uważają, że pierwotne siedziby przedstawicieli linii genealogicznej M458 mieściły się na obszarze dzisiejszej Polski ${ }^{93}$. Najwyższy obecnie udział tej mutacji także występuje wśród Słowian zachodnich (maksimum u Serbów łużyckich). Przewaga dyfuzji kulturowych i ruchów migracyjnych w kierunku wschodnim przed wczesnym średniowieczem (kultura łużycka, kultura pomorska, kultura przeworska i kultura wielbarska) pozwala przypuszczać, że dopiero w wyniku tych procesów przedstawiciele tej linii pojawili się na wschód od dorzecza Wisły. To oni mogli przenieść na wschód także język prasłowiański, bo tam, gdzie obecnie M458 występuje w małym odsetku, tam przetrwały języki bałtyckie i fińskie. Tak powstałby wschodni wariant prasłowiańszczyzny, z której na przełomie starożytności i średniowiecza uformował się dominujący wariant języka słowiańskiego.

Taka interpretacja sprzyjałaby koncepcji sugerującej, że prasłowiańszczyzna ukształtowała się bardziej na zachodzie (dorzecze Odry i Wisły?) niż wschodzie (dorzecze Dniepru?) i dopiero później (ale jeszcze przed końcem starożytności) rozprzestrzeniła się również na wschód. Nie stoi to, moim zdaniem, w sprzeczności z koncepcją, że na progu średniowiecza główny ośrodek Słowiańszczyzny mógł się znajdować już bardziej na wschodzie (między Dniestrem a Dnieprem), tak jak to opisał Jordanes i jak sugeruje lokalizacja najstarszych siedzib kultury prasko-korczakowskiej. Tam mogła się uformować Słowiańszczyzna w jej ostatecznym, wczesnośredniowiecznym kształcie kulturowym i językowym (i z nową, dla tej nowej etnicznej jakości nazwą), asymilując następnie pokrewne ludy na zachodzie (Prasłowianie) i wschodzie (Bałtowie), a także inne ludy w wyniku dalszej ekspansji: Czudź (ludy fińskie) na północnym wschodzie i mieszkańców Bałkanów na południu.

${ }^{91}$ S. Karachanak et al., Y-chromosome diversity..., op. cit.

92 P. A. Underhill et al., The phylogenetic..., op. cit.

${ }_{93}$ Ibidem. 
Tę ostatnią możliwość (oczywiście bez odniesień do badań genetycznych) sugerował J. Strzelczyk, nazywając zachodnich pobratymców Słowian po prostu Wenedami i Prasłowianami jednocześnie. Najwyraźniejszym archeologicznym świadectwem ich przetrwania i odrębności miała być według niego przede wszystkim kultura Sukow-Dziedzice ${ }^{94}$.

Należy natomiast odrzucić hipotezę, że linia genealogiczna M458 mogła znaleźć się wśród Słowian dzięki ludom irańskim (np. Sarmatom) lub ałtajskim (np. Awarom). Wysoki udział M458 szczególnie u Słowian zachodnich (Serbowie łużyccy), przy znacznie mniejszym u Słowian wschodnich, oraz brak tej linii genealogicznej u ludów irańskich i ałtajskich jest tu istotnym argumentem. Wśród ludów irańskich dominuje tradycyjnie linia genealogiczna R1a-Z93, która wśród ludów słowiańskich jest rzadkością i występuje raczej na wschodzie. Haplogrupy Y-DNA, jakie odnaleziono w pochówkach Awarów, uwidaczniają natomiast wyraźną dominację linii genealogicznych charakterystycznych dla ludów ałtajskich: N1a1a1a1a3, R1a1a1b2a (Z93>Z94), C2 i brak zachodniosłowiańskiego R1a-M4589.

Wielu badaczy (np. J. Godłowski, M. Parczewski, A. Kokowski) sądzi, że Słowianie, migrujący we wczesnym średniowieczu ze wschodu w dorzecze Wisły i Odry, nie napotkali jednak pokrewnych sobie Prasłowian, ale przede wszystkim Wandalów (kultura przeworska), czyli lud uważany za germański. Dlaczego jednak pod względem udziału linii genealogicznych byłby on bliższy Słowianom (dominacja R1a z mutacjami M548 i Z280), a nie innym ludom germańskim? Wytłumaczyć to można na dwa sposoby: albo Wandalowie stanowili tylko nieliczną elitę i rządzili ludem prasłowiańskim, albo byli zgermanizowanymi Prasłowianami. Osobiście jestem za tą pierwszą wersją. Gdyby Wandalowie powstali ze zmieszania ludów germańskich i słowiańskich, bo tylko w ten sposób można by wytłumaczyć germanizację Prasłowian, to efekt tego zmieszania widoczny byłby w strukturze linii genealogicznych dzisiejszej Polski (bo część ludności musiała pozostać na ziemiach polskich). Haplogrupy I1, R1a (ale z mutacjami Z284 i L664) i R1b, licznie występujące u ludów germańskich, wyróżniałyby wyraźniej dzisiejszą Polskę od Ukrainy. Różnice te są zaś niewielkie (a te, które są, można wythumaczyć późniejszą kolonizacją niemiecką na ziemiach polskich), co wskazuje, że nie następowało na dużą skalę mieszanie się Germanów i Prasłowian na ziemiach polskich w starożytności. Sugerować to może, że Germanowie odeszli (pociągając z sobą ewentualnie część Prasłowian), a Prasłowianie zostali.

94 J. Strzelczyk, Od Prastowian..., op. cit.

${ }_{95}$ E. Neparáczki et al., 2019, Y-chromosome haplogroups from Hun, Avar and conquering Hungarian period nomadic people of the Carpathian Basin, https://www.biorxiv.org/content/biorxiv/ early/2019/04/03/597997.full.pdf [dostęp: 25.05.2019]. 
Powyższą koncepcję wydają się potwierdzać już pierwsze badania wykorzystujące markery genetyczne w rozwiązywaniu problemu lokalizacji słowiańskiej ojczyzny, których wyniki opublikowane zostały w 2007 r. Rezultaty analizy interpolacyjnej haplotypów Y-DNA (Y-STR) wykluczyły wówczas znaczący wkład plemion starożytnych zamieszkujących dzisiejszą Polskę w pulę genową Słowian wschodnich i południowych oraz sugerowały, że w ekspansji słowiańskiej na Bałkany uczestniczyli jedynie migranci z obszaru dzisiejszej Ukrainy ${ }^{96}$. Oznacza to jednak równocześnie, że - inaczej niż na Bałkany - nad Wisłę i Odrę nie dotarła znacząca ekspansja Słowian ze wschodu. Także wstępne badania nad kopalnym DNA nie zaprzeczają możliwości kontynuacji osadnictwa na ziemiach polskich między starożytnością a średniowieczem ${ }^{97}$.

\section{Interpretacje geograficzne}

W rozważaniach nad etnogenezą Słowian nie można zignorować szczególnych cech „pomostu bałtycko-czarnomorskiego”, na którym to lokowani są Wenetowie, a następnie Sklawenowie. Ów pomost w pewnym stopniu można utożsamić również z Niżem Europejskim jako jednostką geopolityczną ${ }^{98}$. Położenie ,pomostowe" między obu morzami jest podstawą myśli geopolitycznej Eugeniusza Romera. Jego zdaniem polityka jagiellońska, zmierzająca do zintegrowania tego zwartego obszaru w ramach jednego państwa, była zgodna $\mathrm{z}$ układami fizjograficznymi ${ }^{99}$. Odrzucając skrajny determinizm tego poglądu, nie można nie dostrzec, że, zgodnie $\mathrm{z}$ poglądem posybilistycznym $\mathrm{w}$ geografii ${ }^{100}$, środowisko geograficzne pomostu bałtycko-czarnomorskiego mogło sprzyjać tworzeniu pewnych układów przestrzennych dotyczących osadnictwa i organizacji politycznej. Byłaby to ogólna prawidłowość, działająca nie tylko w czasach późnego średniowiecza i nowożytności, ale także w czasach Wenetów i wczesnych Słowian. Tę prawidłowość potwierdzają również dzieje Gotów, które w przypadku ich wschodnioeuropejskiego okresu roz-

${ }^{66}$ K. Rębała et al., Y-STR Variation among Slavs: Evidence for the Slavic Homeland in the Middle Dnieper Basin, „Journal of Human Genetics”, 52(5), 2007, ss. 406-414.

${ }_{97}$ A. Juras, Etnogeneza Stowian w świetle badań kopalnego DNA, praca doktorska, Poznań, Uniwersytet im. Adama Mickiewicza w Poznaniu, 2012, https://repozytorium.amu.edu.pl/handle/10593/2702 [dostęp: 25.05.2019].

${ }^{98}$ L. Moczulski, Geopolityka. Potęga w czasie i przestrzeni, Warszawa, Dom Wydawniczy Bellona, 1999.

${ }_{99}$ P. Eberhardt, Twórcy polskiej geopolityki, Kraków, Arcana, 2006.

${ }^{100}$ A. Piskozub, Między historiozofia a geozofią: szkice z filozofii czasoprzestrzeni ludzkiej, Gdańsk, Uniwersytet Gdański, 1994. 
grywają się właśnie na obszarze pomostu bałtycko-czarnomorskiego (od Bałtyku po Morze Czarne $)^{101}$.

Fenomen pomostu bałtycko-czarnomorskiego wyjaśnić można z jednej strony ograniczeniem go od południowego zachodu przez barierę Karpat i Sudetów, od północnego wschodu zaś przez bezkres odrębnych pod względem przyrodniczym obszarów tzw. Heartlandu, na południu suchych i stepowych, na północy chłodnych i porośniętych tajgą. W ten sposób przestrzenią rozwoju i wzajemnego oddziaływania stawały się właśnie obszary pomostu, czyli dorzecza Wisły, Dniepru, Dniestru i Bohu, ograniczone Karpatami, Sudetami i obydwoma morzami.

Symbolem jedności pomostu bałtycko-czarnomorskiego może być koncepcja Bugu i Bohu, jako wyznaczników ważnego szlaku transportowego. W średniowieczu Bug był łącznikiem między Mazowszem a księstwem halickim, z którym łączyły władców Mazowsza rozległe powiązania dynastyczne. W starożytności, na początku naszej ery, był on ogniwem pomostu pomiędzy Bałtykiem a Morzem Czarnym. Tędy wiodła droga Gotów znad Zatoki Gdańskiej ku ich nowej siedzibie na ziemiach dzisiejszej Ukrainy. Oni to według niektórych badaczy mieli nadać rzece tę nazwę. Gdy Goci doszli do źródeł Bugu, znaleźli w pobliżu początek innej rzeki, która doprowadziła ich w strefę czarnomorską i którą również nazwali Bugiem (Bug Południowy - Jużnyj Boh). Postawiono również tezę, że Goci nazywali Bugiem całą trasę wodną, którą wędrowali na południe, a więc również dolny odcinek dzisiejszej Wisły ${ }^{102}$. Brak barier orograficznych pomiędzy dorzeczami (jak np. Karpaty między dorzeczem Wisły i Dunaju) sprzyjał w przenikaniu z dorzecza Wisły w kierunku Morza Czarnego oraz z dorzeczy Dniepru, Bohu i Dniestru w kierunku Morza Bałtyckiego.

Opisane uwarunkowania fizjograficzne rzeczywiście musiały mieć istotne znaczenie w kształtowaniu się ruchów osadniczych i wpływów politycznych. Z dorzecza Wisły na wschód (Wołyń, Podole) rozprzestrzeniała się w III tys. p.n.e. neolityczna kultura amfor kulistych ${ }^{103}$, trzciniecki krąg kulturowy obejmował dorzecza Odry, Wisły i Dniepru ${ }^{104}$, na wschód z dorzecza Wisły ekspandowała kultura łużycka (pod jej wpływem ukształtował się m.in. kultura wysocka) ${ }^{105}$. Podobną rolę mogła

${ }^{101}$ J. Strzelczyk, Goci..., op. cit.

${ }^{102}$ T. Zipser, Rzeki w kształtowaniu się regionów, „Rzeki. Kultura - Cywilizacja - Historia” 1997, t. VI, ss. 107-122; A. Piskozub A., Jakiej monografii Odry nam potrzeba? Przesłanki metodologiczne monografii wielkiej battyckiej rzeki, [w:] K. Schlögel, B. Halicka (red.), Odra-Oder. Panorama europejskiej rzeki, Skórzyn, Wydawnictwo Instytutowe, 2008, ss. 55-68.

${ }^{103}$ T. Wiślański, 1963, Próba wyświetlenia genezy tzw. kultury amfor kulistych, „Archeologia Polski”, 8(2), ss. 222-245.

${ }^{104} \mathrm{H}$ Д. Лучинский, Тшинеикий культурный круг в проблеме этногенеза славян, „Вестник Московского государственного областного университета", 2, 2018, ss. 89-96.

${ }^{105} \mathrm{~J}$. Gąssowski, Dzieje i kultura dawnych Słowian, do X wieku, Warszawa, Państwowe Zakłady Wydawnictw Szkolnych, 1964. 
odegrać kultura pomorska w formowaniu się nad Dnieprem kultury zarubinieckiej ${ }^{106}$ czy wreszcie kultura przeworska, a szczególnie wielbarska, z dzisiejszych ziem polskich miała istotne znaczenie w powstawaniu nowych kultur późnej starożytności na obszarze dzisiejszej Ukrainy (np. kultury czernichowskiej) ${ }^{107}$. Thumaczyłoby to występowanie słowiańskiej hydronimii przede wszystkim w dorzeczach Wisły i Odry oraz zachodniej części ziem dzisiejszej Ukrainy.

Potwierdzałyby to biologiczne cechy populacji tego obszaru. Wyniki ostatnich badań podkreślają bowiem kontynuację cech morfometrycznych ludów zamieszkujących na obszarze pomostu bałtycko-czarnomorskiego, utrzymujących się od starożytności do średniowiecza, podtrzymując tezy, które znacznie wcześniej przedstawił Jan Czekanowski ${ }^{108}$. Istotnym argumentem jest również podobieństwo struktury męskich linii genealogicznych na tym obszarze (Polska, Ukraina). Charakteryzuje się ona dużym udziałem nosicieli haplogrupy R1a (44-57\%) z dominacją mutacji M458 i Z280, zachowujących pomiędzy sobą względną równowagę, co jest cechą wspólną Polski i Ukrainy i wyróżnia je na tle krajów sąsiednich ${ }^{109}$.

\section{Słowianie południowi}

Problemy z ustaleniem siedzib Słowian pod koniec starożytności utrudniają rekonstrukcję przebiegu ich ekspansji we wczesnym średniowieczu. W miarę jasny obraz mamy jedynie w przypadku Bałkanów, gdzie przed V w. prawdopodobnie w ogóle nie było ludności słowiańskiej (prasłowiańskiej). Opuszczając swoje pierwotne siedziby, Słowianie zasiedlili początkowo (przełom V i VI w.?) Nizinę Wołoską i Panońską (czyli Dację i Panonię), gdzie mieszali się z miejscową ludnością różnego pochodzenia ${ }^{110}$. Następnym krokiem było przełamanie linii Dunaju i początek osadnictwa Słowian na obszarze całego Półwyspu Bałkańskiego (koniec VI w.). Słowianie bądź wypierali miejscową ludność, bądź wchodzili z nią w relacje. Na niektórych obszarach z biegiem czasu miejscowa ludność ulegała slawizacji, gdzie indziej to znowu Słowianie przyjmowali kulturę i język miejscowych ludów ${ }^{111}$. Proces ten znajduje potwierdzenie w zjawiskach językowych (najsilniejszej „bałkani-

${ }^{106}$ В.В. Седов, Происхождение..., ор. cit.

${ }^{107}$ J. Strzelczyk, Goci..., op. cit.

${ }^{108}$ J. Piontek, B. Iwanek, S. Segeda, Antropologia o pochodzeniu..., op. cit.

${ }^{109}$ P. A. Underhill et al., The phylogenetic..., op. cit.

${ }^{110}$ Z. Kurnatowska, Stowianie Poludniowi, [w:] M. Salamon i J. Strzelczyk (red.), Wędrówka i etnogeneza..., op. cit., ss. 231-250.

${ }^{111}$ Ibidem; S. Turlej, Trwanie i zmiany. Stosunki etniczne na Batkanach $w$ okresie VI-X w., [w:] M. Salamon i J. Strzelczyk (red.), Wędrówka i etnogeneza ..., op. cit., ss. 251-267. 
zacji” uległ niewątpliwie język bułgarski, zaliczany wraz z rumuńskim, albańskim i greckim do bałkańskiej ligi językowej ${ }^{112}$ ) oraz we współczesnym przemieszaniu męskich linii genealogicznych (tab. 1).

W nawiązaniu do konkluzji z poprzedniego rozdziału, sugerującej, że kolebką Słowian bałkańskich były ziemie dzisiejszej Ukrainy, można przyjąć, że udział poszczególnych linii genealogicznych na dzisiejszej Ukrainie jest najbliższy stanowi występującemu u Słowian przed ekspansją.

Na południu zaś Słowianie musieli wchłonąć miejscową, wcześniej zromanizowaną i zhellenizowaną, ludność Bałkanów, głównie potomków Traków, Daków i Illirów. Potwierdzają to wyniki badań archeologicznych, przekazy historyczne oraz językoznawcy ${ }^{113}$. Współczesne nam badania sugerują, że ludność ta różniła się także z uwagi na udział poszczególnych linii genealogicznych. W stosunku do dzisiejszych Ukraińców widzimy znaczne obniżenie udziału linii genealogicznej R1a i wyraźnie podwyższony udział takich linii genealogicznych jak I2, E, J. Oznacza to, że miejscowe ludy musiały mieć mniej R1a, a więcej tych pozostałych haplogrup, co potwierdzają dzisiejsze badania genetyczne nad ludami bałkańskimi, które się nie zeslawizowały. Szczególnie Albańczycy i Grecy mają więcej od Słowian południowych linii E i J. Rumuni są pod tym względem mniej wyraziści, co każe przypuszczać, że wchłonęli znacznie więcej przybyszów z północy niż Albańczycy i Grecy (świadczyć może o tym także wyjątkowo duża liczba slawizmów w języku rumuńskim $\left.{ }^{114}\right)$.

Najbardziej zastanawia sytuacja występująca u Słowian zachodniobałkańskich, gdzie dominuje linia I2 (Tab. 1). Gdybyśmy nie wiedzieli, skąd wyszła słowiańska ekspansja, moglibyśmy rozważać możliwość, że to właśnie ta linia dominowała wśród pierwotnych Słowian. Dość wysoki udział mężczyzn należących do tej linii występuje bowiem także na Ukrainie i Białorusi (ok. 20\%). Wiemy jednak, że słowiańska ekspansja na Bałkany wyszła z ziem dzisiejszej Ukrainy, a nie na odwrót, więc to nie I2, ale R1a musiała być szczególnie liczną linią genealogiczną u pierwotnych Słowian. Na Ukrainie dominuje (44\%), a u Słowian południowych jest ona liczna (Bułgaria - 17\%, Słowenia - 38\%) ${ }^{115}$, wyróżniając ich od Greków

\footnotetext{
${ }^{112}$ A.F. Majewicz, Języki świata i ich klasyfikowanie, Warszawa, PWN, 1989.

${ }^{113}$ A. Sołtysiak, Przyczyny ekspansji Stowian we wczesnym średniowieczu, wykład on-line, Stowarzyszenie „Niklot”, 24 kwietnia 2019, www.youtube.com/watch?v=kllkjWdrZmA [dostęp: 25.05.2019].

${ }^{114}$ A. Oczko, Zapożyczenia południowostowiańskie w języku rumuńskim w XVI i XVII wieku, praca doktorska, Kraków, Uniwersytet Jagielloński, Wydział Filologiczny, https://ruj.uj.edu.pl/xmlui/ bitstream/handle/item/41490/oczko_zapozyczenia_poludniowoslowianskie_w_jezyku_rumunskim_2010.pdf [dostęp: 25.05.2019].

${ }^{115} \mathrm{~V}$. Battaglia et al., Y-chromosomal evidence of the cultural diffusion of agriculture in Southeast Europe, „European Journal of Human Genetics”, 17(6), 2009, ss. 820-830.
} 


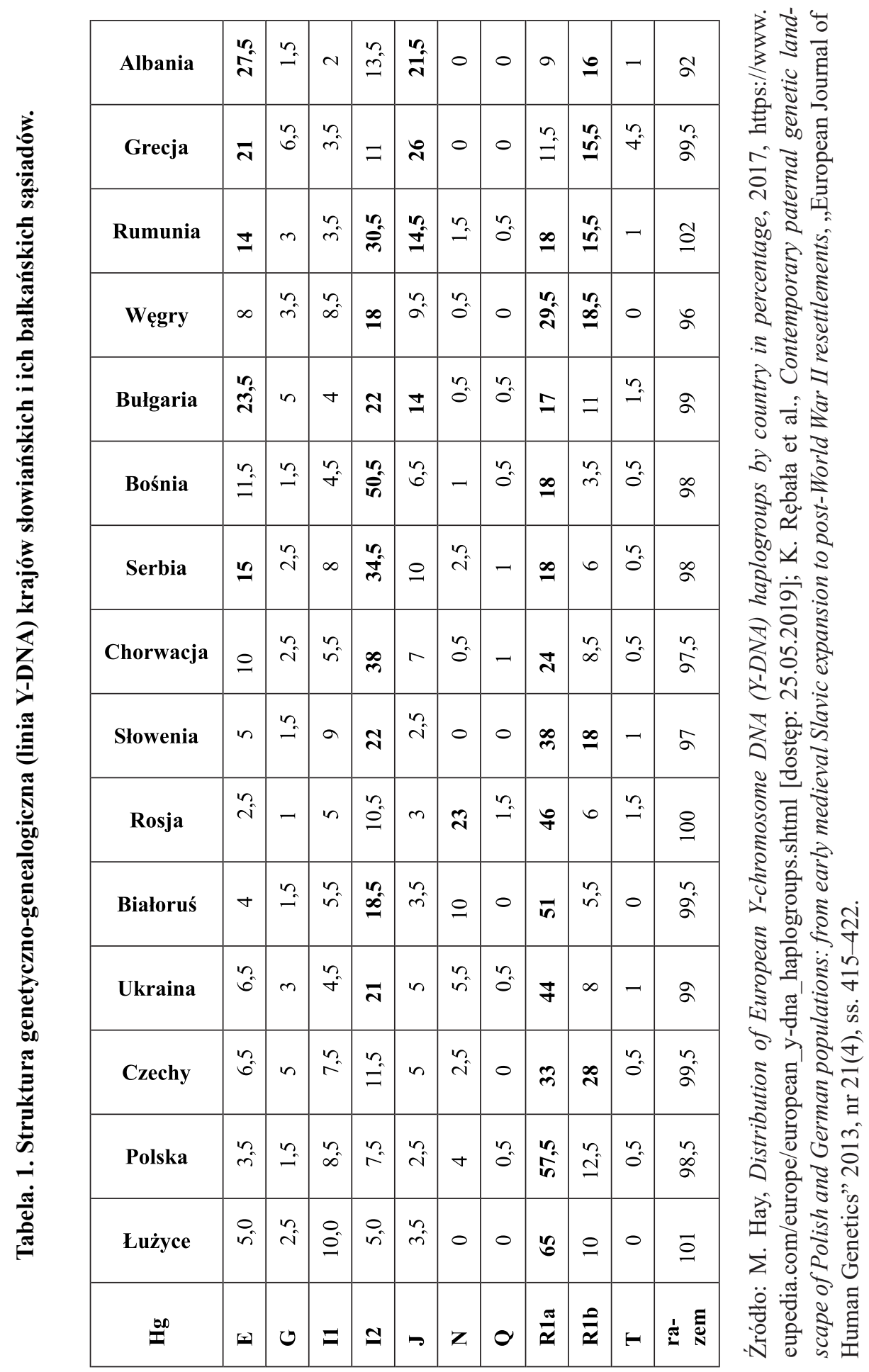


(11,5\%) i Albańczyków (9\%), gdzie przecież też doszła jakaś słowiańska domieszka (np. północna Grecja, Peloponez). Przed ekspansją słowiańską linia I2 musiała być szczególnie liczna u potomków zromanizowanych Illirów, którzy, jak widać, ulegli następie całkowitej slawizacji, stając się przede wszystkim przodkami dzisiejszych Chorwatów, Bośniaków, Serbów i Czarnogórców.

Wśród dzisiejszych ludów słowiańskich najmniej przodków wywodzących się od pierwotnych Słowian wydają się posiadać peryferyjnie usytuowani i izolowani Czarnogórcy (niewielki, ok. 10\%, udział linii genealogicznej R1a). Wśród ludów autochtonicznych największy udział przodków słowiańskiego pochodzenia posiadają natomiast Rumuni. Badania genetyczne sugerują jednak, że jeszcze więcej Słowian wchłonęli późniejsi przybysze - Madziarzy. W przypadku tych ostatnich znaczący proces asymilacji Słowian (głównie Słowaków, Chorwatów, Rusinów i Serbów) trwał jednak do XX w. Aż 5\% dzisiejszych Węgrów ma nazwiska nawiązujące do słowiańskich etnonimów w języku węgierskim (Toth, Horvath, Orosz, Racs, Lengyel, Cseh, Polak) ${ }^{116}$, co można uznać jedynie za wierzchołek góry lodowej. Dodatkowo nazwiska obcego pochodzenia (zasadniczo słowiańskiego, germańskiego i rumuńskiego) stanowią wciąż, pomimo tendencji do madziaryzacji, 30-40\% wszystkich węgierskich nazwisk ${ }^{117}$. To oczywiste świadectwo procesów postępujących w ostatnich stuleciach. Już jednak w szczątkach kopalnych madziarskiej elity z okresu podboju Kotliny Panońskiej około 14\% mężczyzn należało do linii genealogicznej R1a, we wszystkich przypadkach z mutacją Z280 ${ }^{118}$.

Sytuacja ta tym bardziej umacnia w przekonaniu, że linia genealogiczna R1a z dominacją mutacji M458 i/lub Z280 musiała być szczególnie liczna u pierwotnych, uformowanych na północy, Słowian. Dopiero wtórnie, wszędzie tam, gdzie zawędrowali Słowianie, te mutacje stały się również znaczące, choć mniej liczne niż na terenach wyjściowych. Pozwala to nam oceniać, jaki był udział mężczyzn, potomków pierwotnych (sprzed ekspansji) Słowian w formowaniu różnych grup etnicznych. Na Bałkanach jest to od 70-90\% w Słowenii do 30-40\% w Bułgarii.

Rozwój na Bałkanach struktur politycznych związanych z ludami słowiańskimi doprowadził ostatecznie do uformowania się kilku trwałych monarchii słowiańskich - przede wszystkim Bułgarii, Serbii i Chorwacji. Żyjący na północnym zachodzie

${ }^{116}$ T. Farkas, Surnames of ethnonymic origin in the Hungarian language, [w:] O. Felecan (red.), Name and Naming. Proceedings of the Second International Conference on Onomastics. Onomastics in Contemporary Public Space, Cluj-Napoca, Editura Mega - Editura Argonaut, 2013, ss. 504-517.

${ }^{117}$ T. Farkas, Surnames of Foreign Origin in a Language Contact Situation. The Reasons and Ways of Their Changes and Their Influence on the Surname Stock in Hungary, [w:] W. Ahrens (red.), Names in Multi-Lingual, Multi-Cultural and Multi-Ethnic Contact, Toronto, York University, 2009, ss. $365-374$.

${ }^{118}$ E. Neparáczki et al., Y-chromosome haplogroups..., op. cit. 
Chorutanie (przodkowie Słoweńców) bardzo szybko dostali się pod panowanie niemieckie, zachowując jednak swoją odrębność etniczną (podobnie jak Słowacy na Węgrzech i Serbowie łużyccy w Niemczech). Tradycja istnienia tych odrębnych monarchii i grup etnicznych przyczyniła się w epoce nowoczesnej do uformowania się słowiańskich narodów i państw narodowych: bułgarskiego, serbskiego, chorwackiego i słoweńskiego. Wydaje się, że o powstaniu Macedonii, Bośni i Czarnogóry zdecydowały przede wszystkim późniejsze uwarunkowania geopolityczne. Wiele plemion słowiańskich uległo jednak akulturacji, stając się bazą demograficzną społeczeństw niesłowiańskich. Taki los spotkał m.in. Jezierców na Peloponezie, którzy ulegli hellenizacji.

\section{Słowianie zachodni}

Znacznie trudniej prześledzić rozwój osadnictwa słowiańskiego w Europie Środkowej. Jak zauważono wcześniej, podstawa demograficzna Słowian zachodnich nie mogła uformować się w wyniku migracji ze wschodu lub południa. Badania genetyków wskazują bowiem, że napływ ze wschodu i ewentualnie wtórnie z Panonii był tu słabszy niż napływ z ziem dzisiejszej Ukrainy na Bałkany. Dodatkowo pod względem genetyczno-genealogicznym odrębność Słowian zachodnich (Polaków, Czechów, Serbów łużyckich) względem ludów niesłowiańskich (np. Bałtów) rysuje się bardziej wyraziście (duży odsetek przedstawicieli linii R1a i skłonność do dominacji mutacji M458 nad Z280) niż odrębność Ukraińców.

Na tej podstawie można przypuszczać, że dorzecze Wisły i Odry również zamieszkiwali wymienieni przez Jordanesa Wenedowie (co do dorzecza górnej Wisły możemy być tego pewni dla VI w.) i jedynie nieco później znaleźli się oni pod oddziaływaniem kultury prasko-korczakowskiej (Sklawenów) ${ }^{119}$. W ich wypadku doprowadziło to do powstania odrębnych podgrup tej kultury (np. Mogiła) czy też kultur archeologicznych uznawanych przez niektórych za odrębne (Sukow-Dziedzice), położonych w dalszej odległości od pierwotnych siedzib kultury korczakowskiej i pozostających jedynie pod jej wpływem. Wcześniej zaś dominowałyby na tych terenach tradycje późnoprzeworskie ${ }^{120}$. Z tego powodu roboczą nazwą dla mieszkających tu ludów mogliby być „Wenedowie zachodni”. Słowianie (Sklawenowie) byliby środkowym odłamem tego ludu, Antowie południowowschodnim, a ludy kultury kołoczyńskiej ewentualnie „Wenadami wschodnimi” (ryc. 1). Można przy-

${ }^{119}$ J. Strzelczyk, Od Prastowian..., op. cit.; L. Leciejewicz, Stowianie Zachodni..., op. cit.; M. Parczewski, Idzie nowe..., op. cit.

${ }^{120}$ T. Makiewicz, $W$ sprawie aktualnego..., op. cit. 
jąć, że wszystkie te grupy mówiły podobnym językiem (różnymi dialektami prasłowiańskimi/wendzkimi), natomiast stopniowo zostały podporządkowane (utożsamione) najbardziej ekspansywnym (wyrazistym) Słowianom (Sklawenom) i wszystkie ostatecznie weszły w skład słowiańskiej wspólnoty, przyswajając sklawińską normę językową.

Wobec braku napływu licznych Słowian ze wschodu można by rozważyć hipotezę, że ostatecznej slawizacji zachodniej prasłowiańszczyzny („Wenedów zachodnich”) dokonali nieliczni i późniejsi przybysze z południa. W ten bowiem sposób należałoby rozumieć zapis w kronice Nestora dotyczący pochodzenia Słowian zachodnich:

„Po mnogich zaś latach siedli byli Słowianie nad Dunajem, gdzie teraz ziemia węgierska i bułgarska. I od tych Słowian rozeszli się po ziemi i przezwali się imionami swoimi, gdzie siedli na którym miejscu. Tak więc przyszedłszy, siedli nad rzeką imieniem Morawa i przezwali się Morawianami, a drudzy Czechami nazwali się. A oto jeszcze ciż Słowianie: Biali Chorwaci i Serbowie, i Chorutanie. Gdy bowiem Włosi naszli na Słowian naddunajskich i osiadłszy pośród nich, ciemiężyli ich, to Słowianie ci przyszedłszy, siedli nad Wisłą i przezwali się Lachami, a od tych Lachów przezwali się jedni Polanami, drudzy Lachowie, Lucicami, inni - Mazowszanami, inni - Pomorzanami”'121.

Podobną opinię powiela również anonimowy autor Kroniki papieży $i$ cesarzy (XIII w.), sugerując iż pokonani przez Rzymian (Justyniana) Słowianie, uciekając znad Dunaju (czyli z Panonii), osiedlili się na „polach Germanii” (między Soławą a Wisłą), dając początek Polakom, i w „dolinach Germanii”, dając początek Czechom $^{122}$. O tych wędrówkach jako pierwszy wspomina prawdopodobnie czeski tekst z X w. - Opowiadanie o przekładzie ksiag stowiańskich. Można przypuszczać, że te źródła pisane mówią o autentycznej migracji, która miała miejsce na początku VII w. Mogła mieć ona związek z powstaniem państwa Samona i ,ucieczką” Słowian z Panonii spod bezpośredniego panowania awarskiego (ryc. 1). Hipoteza ta znajduje potwierdzenie w badaniach archeologicznych, z których wynika, że na przełomie VI i VII w. wśród ludów ceramiki praskiej pojawiła się nagle nowa grupa osadników przychodzących z południa, z Panonii ${ }^{123}$.

Co interesujące, bardzo często w owym czasie, choć nie zawsze, niemieccy autorzy oddzielali pojęcie „Słowianie” (Sclavi) od pojęcia „Wenedowie” (Winden/ Winiden). To ostatnie zresztą, co najmniej od IX/X w., bardzo często było stosowano

${ }^{121}$ F. Sielicki (przeł. i oprac.), Nestor..., op. cit.

${ }^{122}$ A. Pleszczyński, Przekazy niemieckie o Polsce i jej mieszkańcach w okresie panowania Piastów, Lublin, Wydawnictwo UMCS, 2016.

${ }^{123}$ D. Třeštík, Powstanie Wielkich Moraw. Morawianie, Czesi i Europa Środkowa w latach 791-871, Warszawa, Wydawnictwa Uniwersytetu Warszawskiego, 2009. 


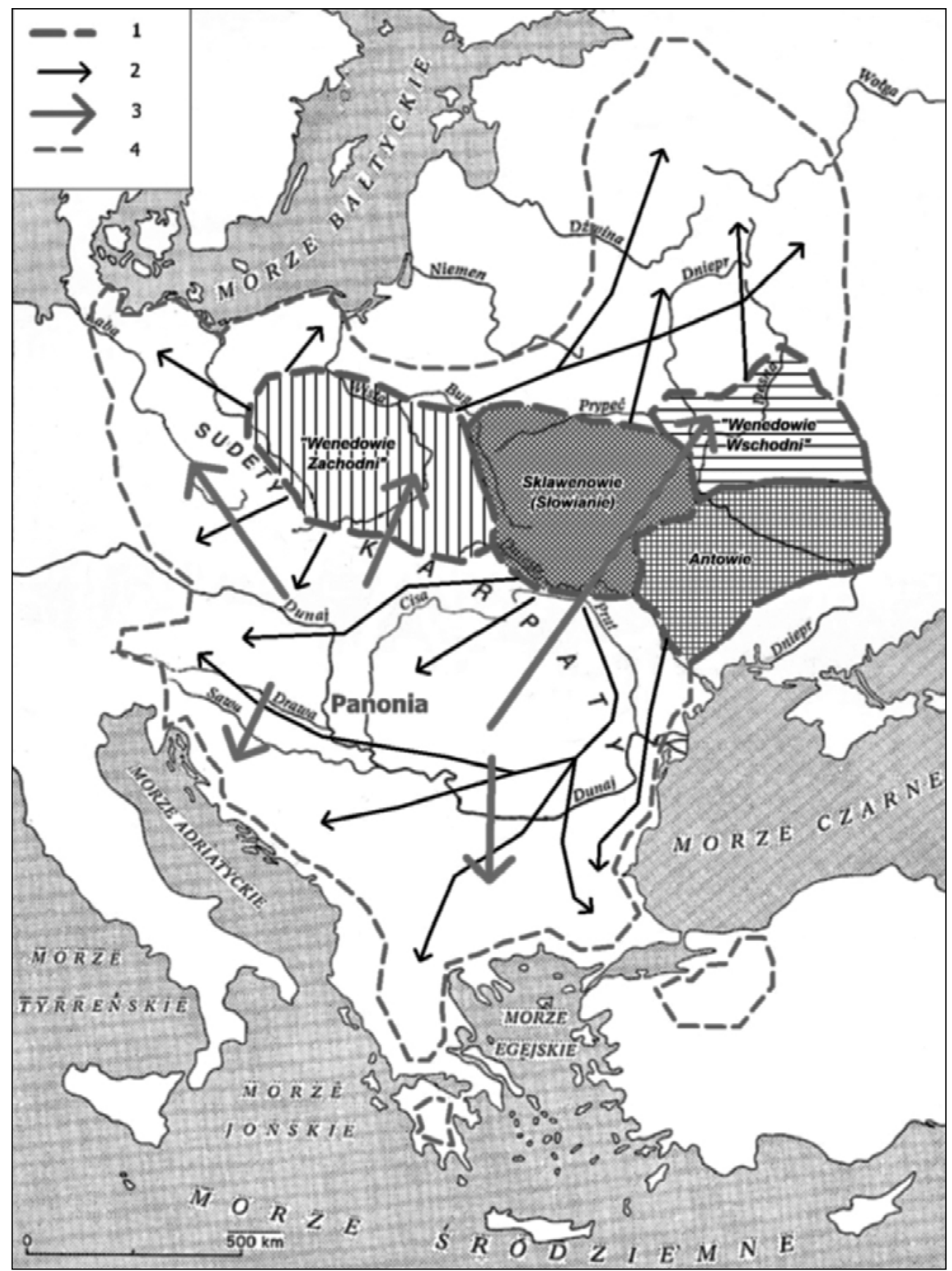

Ryc. 1. Słowiańszczyzna we wezesnym średniowieczu: 1. Ugrupowania prasłowiańskie, 2. Główne kierunki pierwotnej ekspansji Słowian, 3. Wtórna ekspansja Słowian znad Dunaju, 4. Zasięg osadnictwa słowiańskiego w VIII w. Źródło: opracowanie własne. 
wymiennie z określeniem Wandalowie. Tendencja ta nie daje jednak podstaw do utożsamiania starożytnych Wenetów/Wenedów i Wandalów. Nie odrzucając więc hipotezy istnienia jakichś związków pomiędzy obydwoma ludami, należy stwierdzić, że średniowieczni autorzy mogli tak czynić na skutek podobieństwa obu nazw i występowania ich na tym samym obszarze ${ }^{124}$.

Można przypuszczać, że zanim jeszcze nastąpiło ostateczne stopienie się Wenedów i Słowian „Wenedowie zachodni” przemieszczali się w kierunku zachodnim, południowo-zachodnim i północno-zachodnim, zasiedlając ziemie opuszczone przez plemiona germańskie (głównie dorzecze Łaby) i w którymś momencie weszli w kontakt z Germanami zachodnimi. Różne źródła wskazują, że osadnictwo słowiańskie przekroczyło linię Łaby-Soławy (Limes Sorabicus), obejmując część Górnej Frankonii (dolina górnego Menu i Regnitzy) ${ }^{125}$ i Dolnej Saksonii (Drzewianie) ${ }^{126}$. $\mathrm{Na}$ tym obszarze uformowały się plemiona Słowian połabskich: Obodryci, Wieleci, Strodoranie, Serbowie, Miliczanie itd. Zasiedlono również Kotlinę Czeską i dorzecze Morawy, gdzie następnie uformowały się plemiona czeskie. Za Słowian zachodnich uznano także mieszkańców dzisiejszej Polski i Słowacji. Tereny te leżały daleko od ówczesnych centrów cywilizacji europejskiej, co nie sprzyjało szybkiemu uformowaniu się znaczących ośrodków politycznych. Wyjątkiem były Wielkie Morawy, ale znajdowały się one na peryferiach zachodniej Słowiańszczyzny, korzystając z dorobku poprzednich organizmów politycznych: państwa Awarów i rządów Samona. $Z$ tego powodu to one mogły stać się inspiracją dla rozwijających się nieco później monarchii: czeskiej ${ }^{127}$ i polskiej, choć w tym ostatnim przypadku niekoniecznie w takich okolicznościach, jakie ostatnio zaproponował Przemysław Urbańczyk ${ }^{128}$. Jeszcze więcej problemów z dostosowywaniem się do systemu średniowiecznej Europy mieli Słowianie połabscy i pomorscy. W rezultacie formujące się tam księstwa plemienne weszły ostatecznie, podobnie jak Chorutanie na południu, w skład Rzeszy Niemieckiej (Brandenburgia, Saksonia, Meklemburgia, Pomorze). Potomkowie miejscowych Słowian stali się istotną bazą demograficzną formowania wschodnioniemieckich grup regionalnych. Wskazuje na to analiza indywidualnych danych zgromadzonych w bazie FTDNA ${ }^{129}$, a także wyniki wyrywkowych badań

${ }^{124}$ A. Pleszczyński, Przekazy niemieckie..., op. cit.

${ }^{125}$ J. Strzelczyk, Stowianie w pólnocno-wschodniej Bawarii w średniowieczu. Dzieje problemu, „Acta Universitatis Nicolai Copernici. Historia”, 24(204), ss. 155-174.

${ }^{126}$ J. Strzelczyk, Stowianie Połabscy, op. cit.

${ }^{127}$ D. Třeštík, Powstanie Wielkich Moraw..., op. cit.

${ }^{128}$ P. Urbańczyk, Mieszko Pierwszy Tajemniczy, Toruń, Wydawnictwo Naukowe Uniwersytetu Mikołaja Kopernika, 2013.

${ }^{129}$ Linia Łaby-Soławy stanowi wyraźny „uskok” genetyczno-genealogiczny. Obliczenia dokonane przez autora na podstawie danych z FTDNA (www.familytreedna.com) wskazują, że niemieckojęzyczni Prusacy mieszkający przed 1945 r. na wschód od Łaby (Brandenburgia, Pomorze, Dolny Śląsk, 
dotyczących dzisiejszych mieszkańców Niemiec wschodnich ${ }^{130}$. Odrębna, słowiańska przeszłość tych ziem mogła lec u podstaw gospodarczego podziału Niemiec na linii Łaby (dualizm gospodarczy w Europie) ${ }^{131}$ i wpłynęła na liczbę kilku tysięcy zapożyczeń słowiańskich $\mathrm{w}$ zasobie słownikowym dialektów wschodnioniemiec$\mathrm{kich}^{132}$. Ten proces rozpoczął się już w średniowieczu wraz z niemiecką ekspansją polityczną, osadniczą i gospodarczą (kolonizacja na prawie niemieckim) w kierunku wschodnim. W ten sposób, w wyniku kilkusetletniego procesu, uformowało się nowe społeczeństwo niemieckie na wschodzie, dzieląc wiele cech z ludami słowiańskimi, co prawdopodobnie wciąż odgrywa rolę w kształtowaniu różnic kulturowych między tzw. Ossie i Wessie (patrzenie na nie jedynie z perspektywy podziału Niemiec w czasach istnienia NRD i RFN wydaje się zbyt dużym uproszczeniem).

Skomplikowane okoliczności spowodowały, że na obszarze Europy Środkowej ukształtowały się dwie trwałe średniowieczne monarchie słowiańskie: czeska i polska. Dodatkowo formowało się częściowo słowiańskie Królestwo Węgierskie (Uhersko), bo jego integralną częścią była Słowacja (nie wspominając już o wcześniejszym udziale Słowian panońskich w tworzeniu społeczeństwa madziarskiego ${ }^{133}$ ). Prawdopodobnie $\mathrm{z}$ tego powodu to ostatnie przez wielu średniowiecznych autorów także było uznawane za kraj słowiański ${ }^{134}$. Tradycja istnienia tych monarchii zdecydowała następnie o powstaniu w epoce nowoczesnej słowiańskich narodów i państw narodowych: polskiego, czeskiego i słowackiego. Na obszarze Niemiec przetrwała tylko mała grupa Słowian połabskich, tworząca obecnie naród Serbów łużyckich.

Prusy Wschodnie) należeli w ok. 40 \% do linii genealogicznej R1a (głównie mutacje M458 i Z280), co czyniło ich podobnymi bardziej do Polaków niż Niemców z zachodu. Liczba ta może również sugerować, że wśród ich przodków więcej było Prasłowian niż u dzisiejszych Bułgarów (R1a 17\%), Serbów (R1a - 18\%) czy Chorwatów (R1a - 24\%). Nieco mniej R1a, choć nadal dużo, jest w innych wschodnioniemieckich prowincjach: Meklemburgii - 28\%, Saksonii-25\%, Turyngii - 25\% (wszędzie zdecydowana dominacja mutacji M458 i Z280), co wydaje się wskazywać, że również tamtejsze społeczności uformowały się przy znaczącym udziale ludności pochodzenia słowiańskiego. W zachodnich Niemczech R1a to tylko $10-15 \%$ i do tego z dominacją mutacji charakterystycznych dla ludów germańskich (Z284 i L664).

${ }^{130}$ M. Kayser et al., Significant genetic..., op. cit.; D.-U. Immel et al., Y-chromosomal STR haplotype analysis reveals surname-associated strata in the East-German population, „European Journal of Human Genetics" 14, 2006, ss. 577-582.

${ }^{131}$ M. Kowalski, Przedsionek Europy. Miejsce Polski w systemie geopolitycznym nowożytnej Europy, [w:] P. Eberhardt (red.), Studia nad geopolityka XX wieku, „Prace Geograficzne” 242, Warszawa, 2013, ss. 235-263.

132 J. Siatkowski, Historia badań nad wpływami słowiańskimi na język niemiecki, „Gwary Dziś”, 7, 2015, ss. 141-154.

${ }^{133}$ R. Wojna, Wielki świat nomadów. Między Chinami i Europa, Warszawa, Państwowe Wydawnictwo Wiedza Powszechna, 1983.

${ }^{134}$ A. Pleszczyński, Przekazy niemieckie..., op. cit. 


\section{Słowianie wschodni}

Archeologowie sugerują, że Słowianie nie mogli sięgać dalej na północ niż kultura kijowska ${ }^{135}$. Tak samo uważają niektórzy językoznawcy ${ }^{136}$. Obszary na wschód od Dniepru i na północ od Prypeci zamieszkiwały prawdopodobnie plemiona bałtyc$\mathrm{kie}^{137}$, a jeszcze dalej na północ - fińskie ${ }^{138}$. Badania genetyczne pokazują, że mamy tam co prawda pokaźny odsetek linii R1a, ale im dalej na północny wschód, tym mniej jest szczególnie licznej u Słowian mutacji M458. Na Białorusi stanowi ona ok. 1/3 całego R1a, ale w Rosji już tylko ok. 1/4. Mniej niż na Białorusi jest jej na Litwie i Łotwie (1/5), a mniej niż u Rosjan - w rosyjskich narodach ugrofińskich. Potwierdzałoby to tezę, że dla pierwotnych Słowian charakterystyczna była równowaga M458 i Z280 przy jednoczesnej dużej liczebności całego R1a. Na północ i północny wschód od Prypeci prawdopodobnie dużo było R1a, ale z niewielkim udziałem M458, co do dzisiaj jest charakterystyczne dla Bałtów i Finów. Jego wzrost na tych terenach musiał nastąpić dopiero w wyniku średniowiecznej ekspansji Słowian, ale w związku z asymilacją przez nich miejscowych Bałtów i Finów (zdecydowana przewaga Z280) w nowo ukształtowanych społecznościach słowiańskich (Białorusini, Rosjanie) równowaga pomiędzy M458 a Z280 (jak w Polsce i częściowo na Ukrainie) nie mogła zostać zachowana. Dochodzi również, szczególnie u Rosjan (1/5), znaczący odsetek haplogrupy N. Tak jak na Bałkanach, mamy więc wyraźny efekt wchłonięcia przez nowe społeczności słowiańskie przedsłowiańskich autochtonów. Tym bardziej musi zastanawiać brak tak wyrazistego efektu w Polsce, gdyby przyjąć, że i ją skolonizowali Słowianie ze wschodu, absorbując autochtoniczną ludność germańską.

Podobne wnioski wypływają z analizy kroniki Nestora, według której pierwotni Słowianie zamieszkiwali tylko obszar dzisiejszej zachodniej Ukrainy (na zachód od Dniepru). Hipotetycznie, idąc za sugestiami niektórych badaczy ${ }^{139}$, jeszcze ludność kultury kołoczyńskiej moglibyśmy uznać za Prasłowian, czyli „Wenedów wschodnich". Zdaniem Nestora dalej na północnym wschodzie Słowianie mieli pojawić się w podobnych okolicznościach co nad Odrą, Wisłą i Łabą, czyli jako emigranci znad

\footnotetext{
${ }^{135}$ M. Dulinicz, Antropologia fizyczna, archeologia, etnogeneza Stowian, „Archeologia Polski”, 53, 2008, ss. 111-134.

${ }^{136}$ Z. Babik, Wspólnota językowa..., op. cit.

${ }^{137}$ Ł. Okulicz, Osadnictwo strefy..., op. cit.; Z. Babik, Wspólnota językowa ..., op. cit.

${ }_{138}$ Д.А. Мачинский, В.С. Кулешов, Северные народы..., ор. cit.; А.К. Матвеев, К проблеме расселения..., ор. cit.

${ }^{139}$ M. Parczewski, Idzie nowe..., op. cit.
} 
Dunaju ${ }^{140}$ (być może nie z Panonii, tylko obszarów leżących bardziej na wschodzie, np. z Niziny Wołoskiej) (ryc. 1). W ten sposób uformowały się plemiona Polan, Drewlan, Dregowiczów, Połoczan, Słowian ilmeńskich i Siewierzan, pozostawiając swoich ewentualnych pobratymców (Sewercy, Draguwici) na Bałkanach. Jeszcze później, prawdopodobnie znad Wisły („od Lachów”), przybyli Radymicze i Wiatycze. Obraz ten uzupełniali Dulebowie, Chorwaci, Ulicze i Tywercy, którzy przez Nestora mogli być uważani za część pierwotnej i autochtonicznej Słowiańszczyzny (na zachód od Dniepru), bo nie wymienił ich jako przybyłych znad Dunaju.

W odróżnieniu do obszaru zajmowanego przez Słowian południowych i zachodnich, kurczącego się pod wpływem hellenizacji, romanizacji i germanizacji, obszar Słowiańszczyzny wschodniej ulegał stałemu powiększaniu. Wiązało się to przede wszystkim z ekspansją osadniczą i kulturową w kierunku północno-wschodnim, rozpoczętą już w średniowieczu i trwającą praktycznie do dzisiaj. Najpierw wyparte zostały dialekty bałtyckie, później także fińskie i tureckie. Świadectwem tego procesu są relikty ludów bałtyckich (Litwini, Łotysze), fińskich (Estończycy, Wepsowie, Maryjczycy, Mordwini, Karelczycy, Komiacy, Umurcy) i tureckich (Czuwasze, Tatarzy kazańscy), otaczające szerokim łukiem obszary zeslawizowane. Po Bałtach wschodnich (np. Goliadź), Merii, Meszczerze, Muromie i Czudzi zawołockiej pozostały tylko stanowiska dawnych kultur archeologicznych (np. kultura diakowska ${ }^{141}$ ) i odmienne od dominujących wśród pierwotnych Słowian linie genealogiczne (np. wysoki udział haplogrupy Y-DNA N). Procesem slawizacji grup bałtyckich i fińskich można by tłumaczyć także niewielkie zróżnicowanie dialektalne niektórych obszarów Rosji1 ${ }^{142}$.

Początkowo wszystkie plemiona wschodniosłowiańskie zostały zjednoczone w ramach Rusi Kijowskiej. W wyniku rozbicia dzielnicowego i rozpadu tego organizmu państwowego ziemie zamieszkane przez Słowian wschodnich zostały wcielone do trzech odrębnych monarchii: Wielkiego Księstwa Moskiewskiego (później Rosja), Wielkiego Księstwa Litewskiego oraz Korony Królestwa Polskiego. Te dwa ostatnie współtworzyły od 1569 r. Rzeczpospolitą Obojga Narodów, w której ziemie dzisiejszej Białorusi należały do Litwy, a ziemie obecnej Ukrainy do Korony. Tradycja tego podziału i jego skutki ukształtowały odrębne grupy narodowe i przyczyniły się do powstania trzech państw narodowych: Rosji, Ukrainy i Białorusi. Niewielki obszar zamieszkany przez Słowian wschodnich znalazł się także w ramach Królestwa Węgierskiego (do 1918 r.). Uformowała się tam (Ruś Zakarpacka) czwarta,

\footnotetext{
${ }^{140}$ F. Sielicki (przeł. i oprac.), Nestor..., op. cit.

${ }^{141}$ А.С. Сыроватко, Юго-восточное Подмосковье в железном веке: к характеристике локальных вариантов дьяковской культуры, Москва, Издательство CheBuk, 2009.

${ }^{142}$ Z. Babik, Wspólnota językowa..., op. cit.
} 
najmniejsza, wschodniosłowiańska grupa narodowościowa, czyli Karpatorusini, do których zaliczani są też polscy Łemkowie.

\section{Zakończenie}

Niniejsze opracowanie stanowi próbę zobrazowania średniowiecznego osadnictwa słowiańskiego. Uwzględniono znane przekazy źródłowe i porównano je z wynikami dotychczasowych badań z zakresu archeologii, językoznawstwa i genetyki genealogicznej. Prócz przedstawienia faktów zdecydowano się również na próbę ich autorskiej interpretacji, przy uwzględnieniu argumentów różnych stron.

Zdaniem autora koncepcja genezy Słowiańszczyzny na wschodzie (dorzecze Dniepru, Bohu, Dniestru) nie stoi w sprzeczności z poglądami polskiej szkoły autochtonicznej. Można bowiem jednocześnie wyróżnić zarówno szeroką strefę osadnictwa prasłowiańskiego (od Odry po Dniepr), jak i ograniczony rdzeniowy obszar słowiański, ukształtowany na wschodzie dopiero pod koniec starożytności. To w ramach tego ostatniego mogła pierwotnie utworzyć się zwarta grupa o słowiańskiej tożsamości, którą to tożsamość przejęły następnie inne społeczności prasłowiańskie.

Spór między autochtonistami i allochtonistami może mieć więc tylko pozorny charakter. Ostatni etap etnogenezy Słowian między Karpatami a Dnieprem i znaczenie powstałej w ten sposób społeczności (Sklawenowie), jej kultury i języka, nie może bowiem prowadzić do przekreślenia dorobku pozostałej części prasłowiańszczyzny, która we wcześniejszym okresie musiała odegrać decydującą rolę w powstawaniu tego nowego (plemiona słowiańskie) zjawiska społeczno-kulturowego i politycznego. Te okoliczności wyjaśniałyby również tempo i zakres przestrzenny rozpowszechniania się tej nowej jakości. Ludy początków kultury prasko-korczakowskiej byłyby bowiem tylko pierwszymi Prasłowianami, którzy przejęli nową, słowiańską, tożsamość. Po nich uczynili to jednak pozostali Prasłowianie (Wenedowie), a dopiero w dalszej kolejności ludy sąsiednie: mieszkańcy Bałkanów, Bałtowie, Finowie i Germanowie.

Analiza interakcji pomiędzy kolejnymi kulturami archeologicznymi, począwszy od epoki brązu (kultury: trzciniecka, wschodniołużycka, pomorska, zarubiniecka, przeworska, wielbarska, czernichowska, kijowska), pozwala przypuszczać, że kultura prasłowiańska (wenedzka) uformowała się w długotrwałym procesie na obszarze pomostu bałtycko-czarnomorskiego (Niżu Europejskiego). Uwagę zwraca przede wszystkim stałe rozszerzanie się kultur archeologicznych z dorzeczy Wisły i Odry w kierunku wschodnim. To na tym rozległym obszarze (od Wisły po Dniepr i Morze Czarne) wymienia się również Wenetów (Wenedów) jako istotny element krajobrazu etnicznego w pierwszej połowie I tysiąclecia n.e. Wydaje się, że to właśnie spośród 
nich w połowie tego tysiąclecia, na skutek wciąż nieznanych okoliczności, wyodrębnili się, na wschód od dorzecza Wisły, Słowianie (Sklawenowie). Był to więc rezultat działania szeregu procesów, które dopiero w pewnym momencie pozwoliły im przejąć wiodącą rolę. Bodziec do ostatecznego wydzielenia się słowiańskiego rdzenia mógł przyjść z zewnątrz, np. w postaci ekspansji jakichś „Słowian” (Suowenoi?, użyczających swojego etnonimu dla oznaczenia nowej jakości kulturowej) i Sarmatów (Chorwatów, Serbów, Antów?) ze wschodu, a także Germanów z zachodu (Gotów, Dudlebów?), ale mógł być też efektem lokalnego procesu (np. fuzji kilku miejscowych kultur). Oba te czynniki mogły działać również jednocześnie. Owocem tego impulsu (procesu) była kultura prasko-korczakowska i jej etniczno-językowe oblicze. Impuls ten legł również u podstaw późniejszego rozszerzania się ludu i kultury. Sam lud był jednak dzieckiem prasłowiańszczyzny, a jego ekspansja nie przybrałaby takich rozmiarów, gdyby nie podatność na przyswajanie tej nowej odmiany kultury przez pobratymcze ludy prasłowiańskie, które uformowały się w wyniku wcześniejszych procesów, tak na zachodzie (dorzecza Wisły i Odry), jak i być może na wschodzie (środkowe dorzecze Dniepru) (ryc. 1). Niewykluczone, że istotną rolę w tym procesie odegrała również wtórna słowiańska ekspansja, jaka w VII w. n.e. wyszła z terenów Panonii. Wydaje się, że tylko wykorzystanie całego prasłowiańskiego (wenedzkiego) potencjału pod przewodem Słowian (ze szczególnym wkładem ewentualnych plemion wiodących: Serbów, Chorwatów, Dulebów, Siewierzan?, Dregowiczów?, być może jeszcze innych społeczności) umożliwiło tak znaczące rozprzestrzenianie się we wszystkich kierunkach, które pozwoliło już tym szeroko rozumianym Słowianom zasymilować sąsiednie ludy i zasiedlić trzecią część Europy. Dzięki temu mogła następnie powstać Europa średniowiecznych monarchii słowiańskich, a jeszcze później, już w epoce industrialnej, Europa dzisiejszych słowiańskich narodów i ich państw.

\section{Literatura}

Allentoft M. et al., Population genomics of Bronze Age Eurasia, „Nature” 2015, nr 522(7555), ss. 167-172.

Anthony D.W, The Horse, the Wheel, and Language: How Bronze-Age riders from the Eurasian steppes shaped the modern world, Princeton, Princeton University Press, 2007.

Babik Z., Najstarsza warstwa nazewnicza na ziemiach polskich $w$ granicach wczesnośredniowiecznej Stowiańszczyzny, Kraków, Universitas, 2001. 
Babik Z., Wspólnota językowa prasłowiańska, [w:] Przeszłość społeczna. Próba konceptualizacji, S. Tabaczyński et al. (red.), Poznań, Wydawnictwo Poznańskie, 2012, ss. 838-851.

Баран В.Д., Славяне в середине I тысячелетия н.э., [w:] Б.А. Рыбаков (red.), Проблемы этногенеза славян, Киев, Наукова думка, 1978, ss. 5-37.

Battaglia V. et al., Y-chromosomal evidence of the cultural diffusion of agriculture in Southeast Europe, „European Journal of Human Genetics” 2009, nr 17(6), ss. 820-830.

Blažek V., From August Schleicher to Sergei Starostin. On the development of the tree-diagram models of the Indo-European languages, „Journal of Indo-European Studies" 2007, nr 35(1), ss. 82-109.

Borowiec K., Kanon wiedzy na temat tzw. etnogenezy Stowian. Czas przełomu, „Kwartalnik Językoznawczy” 2012, nr 1, ss. 1-37.

Bursche A., Wstęp. Barbarzyńskie tsunami, [w:] A. Bursche et al. (red.), Barbarzyńskie tsunami. Okres Wędrówek Ludów w dorzeczu Odry i Wisty, Warszawa-Szczecin, Uniwersytet Warszawski, Muzeum Narodowe w Szczecinie, 2017, ss. 7-15.

Curta F., The Making of the Slavs. History and Archaeology of the Lower Danube Region, c. 500-700, Cambridge, Cambridge University Press, 2001.

Dulinicz M., Antropologia fizyczna, archeologia, etnogeneza Stowian, „Archeologia Polski” 2008, nr 53, ss. 111-134.

Eberhardt P., Twórcy polskiej geopolityki, Kraków, Arcana, 2006.

Farkas T., Surnames of Ethnonymic Origin in the Hungarian Language, [w:] O. Felecan (ed.), Name and Naming. Proceedings of the Second International Conference on Onomastics. Onomastics in Contemporary Public Space, Cluj-Napoca, Editura Mega - Editura Argonaut, 2013, ss. 504-517.

Farkas T., Surnames of Foreign Origin in a Language Contact Situation. The Reasons and Ways of Their Changes and Their Influence on the Surname Stock in Hungary, [w:] W. Ahrens et al. (ed.), Names in Multi-Lingual, Multi-Cultural and Multi-Ethnic Contact, Toronto, York University, 2009, ss. 365-374.

Fokt K., Śladami etnicznej stratygrafii, czyli u źródeł zachodniej połowy Stowiańszczyzny, [w:] M. Salamon i J. Strzelczyk (red.), Wędrówka i etnogeneza w starożytności i w średniowieczu, Kraków, Historia Iagellonica, 2010, ss. 269-289.

Gąssowski J., Dzieje i kultura dawnych Stowian, do X wieku, Warszawa, Państwowe Zakłady Wydawnictw Szkolnych, 1964.

Godłowski K., Pierwotne siedziby Słowian: wybór pism, M. Parczewski (red.), Kraków, Instytut Archeologii Uniwersytetu Jagiellońskiego, 2000.

Gołąb Z., O pochodzeniu Stowian w świetle faktów językowych, Kraków, Universitas, 2004. 
Haak W. et al., Massive migration from the steppe was a source for Indo-European languages in Europe, „Nature” 2015, nr 522(7555), ss. 207-211.

Handschuh L. et al., W poszukiwaniu Piastów, „Opolskie Studia Administracyjno-Prawne" 2016, t. XIV, nr 4(2), ss. 63-77.

Hay M., Distribution of European Y-chromosome DNA (Y-DNA) haplogroups by country in percentage, 2017, https://www.eupedia.com/europe/european_y-dna_ haplogroups.shtml [dostęp: 25.05.2019].

Immel D.-U. et al., Y-chromosomal STR haplotype analysis reveals surname-associated strata in the East-German population, „European Journal of Human Genetics" 2006, nr 14, ss. 577-582.

Juras A., Etnogeneza Stowian w świetle badań kopalnego DNA, praca doktorska, Poznań, Uniwersytet im. Adama Mickiewicza w Poznaniu, 2012, https://repozytorium.amu.edu.pl/handle/10593/2702 [dostęp: 25.05.2019].

Karachanak S. et al., Y-Chromosomal Haplogroups in Bulgarians, „Comptes Rendus de l'Académie Bulgare des Sciences" 2009, nr 62(3), ss. 393-400.

Karachanak S. et al., Y-chromosome diversity in modern Bulgarians: new clues about their ancestry, „PLOS One” 2013, nr 8(3), https://journals.plos.org/plosone/article?id=10.1371/journal.pone.0056779 [dostęp: 25.05.2019].

Kasperaviciūte D. et al., Y chromosome and mitochondrial DNA variation in Lithuanians, „Annals of Human Genetics” 2004, nr 68, ss. 438-452.

Kayser M. et al., Significant genetic differentiation between Poland and Germany follows present-day political borders, as revealed by Y-chromosome analysis, „Human Genetics” 2005, nr 117(5), ss. 428-443.

Kokowski A., Starożytna Polska. Od trzeciego stulecia przed narodzeniem Chrystusa do schytku starożytności, Warszawa, Wyd. Trio, 2005, s. 532.

Kolendo J., Wenetowie w Europie środkowej $i$ wschodniej: lokalizacja i rzeczywistość etniczna, „Przegląd Historyczny” 1984, nr 75(4), ss. 637-653.

Kowalski M., Przedsionek Europy. Miejsce Polski w systemie geopolitycznym nowozytnej Europy, [w:] P. Eberhardt (red.), Studia nad geopolityka XX wieku, „Prace Geograficzne" 2013, nr 242, ss. 235-263.

Kurnatowska Z., Nowe spojrzenie na genezę ceramiki wczesnośredniowiecznej, „Archeologia Polski” 2008, t. LIII, z. 1, ss. 73-80.

Kurnatowska Z., Stowianie Poludniowi, [w:] M. Salamon i J. Strzelczyk (red.), We drówka i etnogeneza w starożytności i w średniowieczu, Kraków, Historia Iagellonica, 2010, ss. 231-250.

Kurnatowska Z., Słowiańszczyzna południowa, Wrocław, Ossolineum, 1977.

Kushniarevich A., The Y chromosome R1A1A7 (M458) haplogroup of modern Belarusians and migrations of ancestors of Slavs on Belarus' territory, „Russian Journal of Genetics: Applied Research" 2012, nr 2, ss. 114-121. 
Kushniarevich A. et al., Uniparental genetic heritage of Belarusians: encounter of rare Middle Eastern matrilineages with a Central European mitochondrial DNA pool, „PLOS One” 2013, nr 8, https://journals.plos.org/plosone/article?id=10.1371/journal.pone.0066499 [dostęp: 25.05.2019].

Kushniarevich A. et al., Genetic Heritage of the Balto-Slavic Speaking Populations: A Synthesis of Autosomal, Mitochondrial and Y-Chromosomal Data, „PLOS One” 2015, nr 10(9), https://journals.plos.org/plosone/article?id=10.1371/journal. pone.0135820 [dostęp: 25.05.2019].

Latałowa M., Przyrodnicze ślady przemian osadniczych między Odra a Wista w I tysiacleciu po Chr., [w:] A. Burscheet (red.), Barbarzyńskie tsunami. Okres Wędrówek Ludów w dorzeczu Odry i Wisty, Warszawa-Szczecin, Uniwersytet Warszawski, Muzeum Narodowe w Szczecinie, 2017, ss. 17-23.

Leciejewicz L., Mały słownik kultury dawnych Stowian, Warszawa, Wiedza Powszechna, 1988.

Leciejewicz L., Stowianie Zachodni: z dziejów tworzenia się średniowiecznej Europy, Wrocław, Ossolineum, 1989.

Ле́бедев Г.С., Вернемся к началу, „Знание - сила” 1986, nr 10, ss. 17-19.

Łapiński Ł., Rla Clades, https://siliusradicum.pl/projekt-silesia/haplogrupy/haplogrupa-r1a/ [dostęp: 25.05.2019].

Łowmiański H., Początki Polski, Warszawa, PWN, 1963.

Łowmiański H., Scytia, [w:] Stownik starożytności słowiańskich, t. V, Wrocław, Ossolineum, 1975, ss. 101-119.

Łowmiański H., Studia nad dziejami Stowiańszczyzny, Polski i Rusi w wiekach średnich, Poznań, Uniwersytet im. Adama Mickiewicza w Poznaniu, 1986.

Лучинский Н.Д. Тшинеикий культурный круг в проблеме этногенеза славян, „Вестник Московского государственного областного университета” 2018, nr 2, ss. 89-96.

Мачинский Д.А., Кулешов В.С., Северные народы середины IV-nервой половины VI в. в „,Getica” Иордана, [w:] Л. и Г. Лебедев (red.), Восьмые чтения памяти Анны Мачинской, 2004, ss. 26-72.

Majewicz A.F., Języki świata i ich klasyfikowanie, Warszawa, PWN, 1989.

Makiewicz T., W sprawie aktualnego stanu badań nad problemem kontynuacji kulturowej pomiędzy starożytnościa a wczesnym średniowieczem w Polsce. Punkt widzenia autochtonisty, „Slavia Antiqua: rocznik poświęcony starożytnościom słowiańskim" 2005, nr 46, ss. 9-38.

Максимов Е.В., Миграчии в жизни древних Славян, [w:] Славяне и Русь (В зарубежной историографии), Киев, Наукова думка, 1990, ss. 5-11.

Malaspina P. et al, Analysis of Y-chromosome variation in modern populations at the European-Asian border, [w:] Ancient Interactions: east and west in Eurasia, 
K. Boyle et al., McDonald Institute for Archaeological Research Monographs, Cambridge University, 2003, ss. 309-313.

Mańczak W., Zagadnienie praojczyzny Stowian, „Przegląd Historyczny” 2003, nr 94(1), ss. 77-81.

Матвеев А.К., К проблеме расселения летописной мери (рус.), „Известия Уральского государственного университета" 1997, nr 7, ss. 5-17.

Матвеева Г.И., Некоторые итоги изучения именьковской культуры, [w:] Этногенез и этнокультурные контакты славян, Труды VI Международного конгресса славянской археологии. Т. 3, Москва, Наука, 1997, ss. 206-217.

Матвеева Г.И., Среднее Поволжье в IV-VII вв.: Именьковская культура, Самара, Самарский университет, 2004.

Mielnik-Sikorska M. et al., Genetic data from Y chromosome STR and SNP loci in Ukrainian population, „Forensic Science International: Genetics” 2013, nr 7, ss. 200-203.

Mielnik-Sikorska M. et al., The History of Slavs Inferred from Complete Mitochondrial Genome Sequences, 2013, https://journals.plos.org/plosone/article?id=10.1371/journal.pone.0054360 [dostęp: 25.05.2019].

Moczulski L., Geopolityka. Potęga w czasie i przestrzeni, Warszawa, Dom Wydawniczy Bellona, 1999.

Moszyński K., Badania nad pochodzeniem i pierwotna kultura Słowian, t. I, Kraków, Polska Akademia Umiejętności, 1925.

Moszyński K., Badania nad pochodzeniem i pierwotna kultura Stowian, „Rozprawy PAU”, t. LXII, nr 2, Kraków 1925.

Moszyński K., Pierwotny zasiag języka prasłowiańskiego, Wrocław, Ossolineum, 1957.

Moszyński L.. Wstęp do filologii stowiańskiej, Warszawa, PWN, 2006.

Mühle E., Die Slaven im Mittelalter, Berlin, De Gruyter, 2016.

Nalepa J., O pierwotnych siedzibach Stowian w świetle nowszych badań archeologicznych, lingwistycznych i historycznych, „Slavia Antiqua: rocznik poświęcony starożytnościom słowiańskim" 2007, nr 48, ss. 11-96.

Narasimhan V.M., The Genomic Formation of South and Central Asia, 2018, https://www.biorxiv.org/content/early/2018/03/31/292581.full.pdf [dostęp: 25.05.2019].

Neparáczki E. et al., 2019, Y-chromosome haplogroups from Hun, Avar and conquering Hungarian period nomadic people of the Carpathian Basin, https:// www.biorxiv.org/content/biorxiv/early/2019/04/03/597997.full.pdf [dostęp: 25.05.2019].

Noińska M., Genetyka populacyjna a problem etnogenezy Stowian, „Studia Rossica Gedanensia" 2016, nr 3, ss. 143-156. 
Oczko A., Zapożyczenia południowosłowiańskie w języku rumuńskim w XVI i XVII wieku, praca doktorska, Kraków, Uniwersytet Jagielloński, Wydział Filologiczny, https://ruj.uj.edu.pl/xmlui/bitstream/handle/item/41490/oczko_zapozyczenia_ poludniowoslowianskie_w_jezyku_rumunskim_2010.pdf [dostęp: 25.05.2019].

Okulicz Ł., Osadnictwo strefy wschodniobattyckiej w I tysiącleciu przed nasza era, Wrocław, Ossolineum, 1976.

Parczewski M., Idzie nowe. Pierwsi Stowianie na ziemiach Polski, [w:] A. Bursche et al., Barbarzyńskie tsunami. Okres Wędrówek Ludów w dorzeczu Odry i Wisty, Warszawa-Szczecin, Uniwersytet Warszawski, Muzeum Narodowe w Szczecinie, 2017, ss. 59-65.

Parczewski M., Wspótczesne poglądy w sprawie etnogenezy oraz wielkiej wędrówki Stowian, [w:] M. Salamon i J. Strzelczyk (red.), Wędrówka i etnogeneza w starożytności i w średniowieczu, Kraków, Historia Iagellonica, 2010, ss. 221-230.

Paszkiewicz H., Początki Rusi, Kraków, Polska Akademia Umiejętności, 1996.

Piontek J., Iwanek B., Segeda S., Antropologia o pochodzeniu Stowian, „Monografie Instytutu Antropologii UAM" 2008, nr 12.

Piskozub A., Jakiej monografii Odry nam potrzeba? Przestanki metodologiczne monografii wielkiej battyckiej rzeki, [w:] K. Schlögel, B. Halicka (red.), OdraOder. Panorama europejskiej rzeki, Skórzyn, Wydawnictwo Instytutowe, 2008, ss. 55-68.

Piskozub A., Między historiozofia a geozofią: szkice z filozofii czasoprzestrzeni ludzkiej, Gdańsk, Uniwersytet Gdański, 1994.

Pleszczyński A., Przekazy niemieckie o Polsce i jej mieszkańcach w okresie panowania Piastów, Lublin, Wydawnictwo UMCS, 2016.

Pliss L. et al., Y-Chromosomal Lineages of Latvians in the Context of the Genetic Variation of the Eastern-Baltic Region, „Annals of Human Genetics” 2015, nr 79(6), ss. 418-430.

Popowska-Taborska H., Wczesne dzieje Stowian w świetle ich języka, Wrocław-Kraków, Ossolineum, 1991.

Reich D., Who We Are and How We Got Here, Oxford, Oxford University Press, 2018.

Rębała K. et al., Contemporary paternal genetic landscape of Polish and German populations: from early medieval Slavic expansion to post-World War II resettlements, „European Journal of Human Genetics” 2013, nr 21(4), ss. 415-422.

Rębała K. et al., Y-STR Variation among Slavs: Evidence for the Slavic Homeland in the Middle Dnieper Basin, „Journal of Human Genetics” 2007, nr 52(5), ss. 406-414.

Ringe D., Warnow T., Taylor A., Indo-European and Computational Cladistics, „Transactions of the Philological Society” 2002, nr 100(1), ss. 59-129. 
Rosser Z.H. et al., Y-chromosomal diversity in Europe is clinal and influenced primarily by geography, rather than by language, „American Journal of Human Genetics" 2000, nr 67(6), ss. 1526-1543.

Siatkowski J., Historia badań nad wpływami słowiańskimi na język niemiecki, „Gwary Dziś” 2015, nr 7, ss. 141-154.

Седов В.В., Происхождение и ранняя история славян, Москва, Наука, 1979.

Седов В.В., Этногенез ранних Славян, „Вестник Российской Академии Наук” 2003, nr 73(7), ss. 594-605.

Sielicki F. (przeł. i oprac.), Nestor - Powieść minionych lat, Wrocław, Ossolineum, 1999.

Skowronek J., Tanty M., Wasilewski T., Historia Stowian południowych i zachodnich, Warszawa, PWN, 1988.

Sołtysiak A., Przyczyny ekspansji Stowian we wczesnym średniowieczu, wykład on-line, Stowarzyszenie „Niklot”, 24 kwietnia 2019, www.youtube.com/ watch?v=klIkjWdrZmA [dostęp: 25.05.2019].

Starostin S., Indo-European glottochronology and homeland, Paper presented at the Prehistoric Chronology Workshop, Santa Fe Institute, March 1-5, 2004.

Strzelczyk J., Goci. Rzeczywistość i legenda, Poznań, Wydawnictwo Poznańskie, 2015.

Strzelczyk J., Od Prastowian do Polaków, Kraków, KAW, 1987.

Strzelczyk J., Stowianie połabscy, Poznań, Wydawnictwo Poznańskie, 2002. Strzelczyk J., Stowianie w pótnocno-wschodniej Bawarii w średniowieczu. Dzieje problemu, „Acta Universitatis Nicolai Copernici. Historia” 1990, nr 24(204), ss. $155-174$.

Sykes B., Adam 's Curse: A Future Without Men, London-New York, Bantam, 2003. Сыроватко А.С., Юго-восточное Подмосковье в железном веке: к характеристике локальных вариантов дьяковской культуры, Москва, Издательство CheBuk, 2009.

Tambets K. et al., The western and eastern roots of the Saami - the story of genetic “outliers” told by mitochondrial DNA and Y chromosomes, „American Journal of Human Genetics" 2004, 74(4), ss. 661-682.

Třeštík D., Powstanie Wielkich Moraw. Morawianie, Czesi i Europa Środkowa w latach 791-871, Warszawa, Wydawnictwa Uniwersytetu Warszawskiego, 2009.

Turlej S., Trwanie i zmiany. Stosunki etniczne na Batkanach w okresie VI-X w., [w:] M. Salamon i J. Strzelczyk (red.), Wędrówka i etnogeneza w starożytności i w średniowieczu, Kraków, Historia Iagellonica, 2010, ss. 251-267.

Tyszkiewicz J., Geografia historyczna Polski w średniowieczu, Warszawa, Wydawnictwo DiG, 2003. 
Tyszkiewicz L.A., Stowianie i Awarowie. Organizacja plemienna Stowian, Wrocław, Ossolineum, 2009.

Tyszkiewicz L.A., Stowianie w historiografii antycznej do połowy VI wieku, Wrocław, Wydawnictwo Uniwersytetu Wrocławskiego, 1990.

Underhill P.A. et al., The phylogenetic and geographic structure of Y-chromosome haplogroup Rla, „European Journal of Human Genetics” 2014, nr 23(1), ss. 124 131.

Wesołowski D. (Davidski), Rla-Z280 from Early Bronze Age Northern Poland, 2017, http://eurogenes.blogspot.com/2017/01/r1a-z280-from-early-bronze-agenorthern.html [dostęp: 25.05.2019].

Wiślański T., Próba wyświetlenia genezy tzw. kultury amfor kulistych, „Archeologia Polski" 1963, nr 8(2), ss. 222-245.

Wojna R., Wielki świat nomadów. Między Chinami i Europa, Warszawa, Państwowe Wydawnictwo Wiedza Powszechna, 1983.

Zakrzewski S., Opis grodów i terytoriów z pótnocnej strony Dunaju czyli tzw. Geograf Bawarski, Lwów, Towarzystwo dla Popierania Nauki Polskiej, 1917.

Zdziebłowski Sz., Nowe dowody na obecność ludzi na terenach Polski w późnej starożytności, http://scienceinpoland.pap.p1/aktualnosci/news\%2C31468\%2Cnowe-dowody-na-obecnosc-ludzi-na-terenach-polski-w-poznej-starozytnosci.html [dostęp: 25.05.2019].

Zipser T., Rzeki w ksztaltowaniu się regionów, „Rzeki. Kultura - Cywilizacja Historia" 1997, t. VI, ss. 107-122.

Жих М.И., Ранние славяне в Среднем Поволжье (по материалам письменных источников), СПб-Казань, Вестфалика, 2011, 90 ss.

\section{References}

Allentoft M. et al., Population genomics of Bronze Age Eurasia, "Nature" 2015, No. 522 (7555), pp. 167-172.

Anthony D.W, The Horse, the Wheel, and Language: How Bronze-Age riders from the Eurasian steppes shaped the modern world, Princeton, Princeton University Press, 2007.

Babik Z., Najstarsza warstwa nazewnicza na ziemiach polskich w granicach wczesnośredniowiecznej Stowiańszczyzny [The oldest naming layer in the Polish lands within the limits of early medieval Slavdom], Kraków, Universitas, 2001.

Babik Z., Wspólnota językowa prasłowiańska [The Prot-Slavic language community], [in:] S. Tabaczyński et al. (ed.), Przeszłość społeczna. Próba konceptualizacji 
[Social past. An attempt to conceptualize], Poznań, Wydawnictwo Poznańskie, 2012, pp. 838-851.

Baran V.D., Slavjane v seredine I tysjacheletija n.je. [Slavs in the middle of I millennium AD], [in:] V.D. Baran, B.A. Rybakov (ed.), Problemy jetnogeneza slavjan, Kiev, Naukova dumka, 1978, pp. 5-37.

Battaglia V. et al., Y-chromosomal evidence of the cultural diffusion of agriculture in Southeast Europe, "European Journal of Human Genetics" 2009, No. 17(6), pp. 820-830.

Blažek V., From August Schleicher to Sergei Starostin. On the development of the tree-diagram models of the Indo-European languages, "Journal of Indo-European Studies" 2007, No. 35(1), pp. 82-109.

Borowiec K., Kanon wiedzy na temat tzw. etnogenezy Stowian. Czas przełomu [The canon of knowledge about the so-called Slavonic ethnogenesis. Breakthrough time], "Kwartalnik Językoznawczy" ["Linguistic Quarterly"] 2012, No. 1, pp. 1-37.

Bursche A., Wstęp. Barbarzyńskie tsunami [Introduction. Barbaric tsunami], [in:] A. Bursche et al. (ed.), Barbarzyńskie tsunami. Okres Wędrówek Ludów w dorzeczu Odry $i$ Wisty, [Barbaric Tsunami. Migration Period in the Odra and Vistula basin], Warszawa-Szczecin, Uniwersytet Warszawski, Muzeum Narodowe w Szczecinie, 2017, pp. 7-15.

Curta F., The Making of the Slavs. History and Archaeology of the Lower Danube Region, c. 500-700, Cambridge, Cambridge University Press, 2001.

Dulinicz M., Antropologia fizyczna, archeologia, etnogeneza Stowian [Physical anthropology, archeology, ethnogenesis of Slavs], "Archeologia Polski” ["Archeology of Poland"] 2008, No. 53, pp. 111-134.

Eberhardt P., Twórcy polskiej geopolityki [The creators of Polish geopolitics], Kraków, Arcana, 2006.

Farkas T., Surnames of Ethnonymic Origin in the Hungarian Language, [in:] O. Felecan (ed.), Name and Naming. Proceedings of the Second International Conference on Onomastics. Onomastics in Contemporary Public Space, Cluj-Napoca, Editura Mega - Editura Argonaut, 2013, pp. 504-517.

Farkas T., Surnames of Foreign Origin in a Language Contact Situation. The Reasons and Ways of Their Changes and Their Influence on the Surname Stock in Hungary, [in:] W. Ahrens et al. (ed.), Names in Multi-Lingual, Multi-Cultural and Multi-Ethnic Contact, Toronto, York University, 2009, pp. 365-374.

Fokt K., Śladami etnicznej stratygrafii, czyli u źródet zachodniej połowy Słowiańszczyzny [In the footsteps of ethnic stratigraphy, that is at the source of the western half of Slavdom], [in:] M. Salamon i J. Strzelczyk (ed.), Wędrówka i etnogeneza 
w starożytności $i$ wśredniowieczu [Wandering and ethnogenesis in ancient and medieval times], Kraków, Historia Iagellonica, 2010, pp. 269-289.

Gąssowski J., Dzieje i kultura dawnych Stowian, do X wieku [History and culture of the old Slavs, up to the tenth century], Warszawa, Państwowe Zakłady Wydawnictw Szkolnych, 1964.

Godłowski K., Pierwotne siedziby Stowian: wybór pism [The original seats of the Slavs: selection of writings], M. Parczewski (ed.), Kraków, Instytut Archeologii Uniwersytetu Jagiellońskiego, 2000.

Gołąb Z., O pochodzeniu Stowian w świetle faktów językowych [On the origin of the Slavs in the light of linguistic facts], Kraków, Universitas, 2004.

Haak W. et al., Massive migration from the steppe was a source for Indo-European languages in Europe, "Nature" 2015, No. 522(7555), pp. 207-211.

Handschuh L. et al., W poszukiwaniu Piastów [In search of Piasts], „Opolskie Studia Administracyjno-Prawne" ["The Opole Studies in Administration and Law"] 2016, Vol. XIV, No. 4(2), pp. 63-77.

Hay M., Distribution of European Y-chromosome DNA (Y-DNA) haplogroups by country in percentage, 2017, https://www.eupedia.com/europe/european_y-dna_ haplogroups.shtml [accessed: May 25, 2019].

Immel D.-U. et al., Y-chromosomal STR haplotype analysis reveals surname-associated strata in the East-German population, "European Journal of Human Genetics" 2006, No. 14, pp. 577-582.

Juras A., Etnogeneza Stowian w świetle badań kopalnego DNA [Ethnogenesis Slavs in the light of ancient DNA], PhD thesis, Poznań, Uniwersytet im. Adama Mickiewicza w Poznaniu, 2012, https://repozytorium.amu.edu.pl/handle/10593/2702 [accessed: May 25, 2019].

Karachanak S. et al., Y-Chromosomal Haplogroups in Bulgarians, "Comptes Rendus de l'Académie Bulgare des Sciences" 2009, No. 62(3), pp. 393-400.

Karachanak S. et al., Y-chromosome diversity in modern Bulgarians: new clues about their ancestry, "PLOS One" 2013, No. 8(3), https://journals.plos.org/plosone/article?id=10.1371/journal.pone.0056779 [accessed: May 25, 2019].

Kasperaviciūte D. et al., Y chromosome and mitochondrial DNA variation in Lithuanians, "Annals of Human Genetics" 2004, No. 68, pp. 438-452.

Kayser M. et al., Significant genetic differentiation between Poland and Germany follows present-day political borders, as revealed by Y-chromosome analysis, "Human Genetics" 2005, No. 117(5), pp. 428-443.

Kokowski A., Starożytna Polska. Od trzeciego stulecia przed narodzeniem Chrystusa do schytku starożytności [Ancient Poland. From the third century before the birth of Christ to the end of antiquity], Warszawa, Wyd. Trio, 2005, p. 532. 
Kolendo J., Wenetowie w Europie środkowej $i$ wschodniej: lokalizacja i rzeczywistość etniczna [Wenets in Central and Eastern Europe: location and ethnic reality], „Przegląd Historyczny” [„Historical Review”] 1984, No. 75(4), pp. 637-653.

Kowalski M., Przedsionek Europy. Miejsce Polski w systemie geopolitycznym nowożytnej Europy [The vestibule of Europe. The place of Poland in the geopolitical system of modern Europe], [in:] P. Eberhardt (ed.), Studia nad geopolityka XX wieku [Studies on the 20th century geopolitics], "Prace Geograficzne" ["Geographical Studies"] 2013, No. 242, pp. 235-263.

Kurnatowska Z., Nowe spojrzenie na geneze ceramiki wczesnośredniowiecznej [A new look at the genesis of early medieval ceramics], „Archeologia Polski” „Archeology of Poland”] 2008, Vol. LIII, No. 1, pp. 73-80.

Kurnatowska Z., Stowianie Poludniowi [South Slavs], [in:] M. Salamon i J. Strzelczyk (ed.), Wędrówka i etnogeneza w starożytności i w średniowieczu [Wandering and ethnogenesis in ancient and medieval times], Kraków, Historia Iagellonica, 2010, pp. 231-250.

Kurnatowska Z., Stowiańszczyzna południowa [Southern Slavs], Wrocław, Ossolineum, 1977.

Kushniarevich A. et al. Uniparental genetic heritage of Belarusians: encounter of rare Middle Eastern matrilineages with a Central European mitochondrial DNA pool, "PLOS One" 2013, No. 8, https://journals.plos.org/plosone/article?id=10.1371/journal.pone.0066499 [accessed: May 25, 2019].

Kushniarevich A. et al., Genetic Heritage of the Balto-Slavic Speaking Populations: A Synthesis of Autosomal, Mitochondrial and Y-Chromosomal Data, "PLOS One" 2015, No. 10 (9), https://journals.plos.org/plosone/article?id=10.1371/journal. pone.0135820 [accessed: May 25, 2019].

Kushniarevich A., The Y chromosome R1A1A7 (M458) haplogroup of modern Belarusians and migrations of ancestors of Slavs on Belarus' territory, "Russian Journal of Genetics: Applied Research" 2012, No. 2(2), pp. 114-121.

Łapiński Ł., Rla Clades, https://siliusradicum.pl/projekt-silesia/haplogrupy/haplogrupa-rla/ [accessed: May 25, 2019].

Latałowa M., Przyrodnicze ślady przemian osadniczych między Odra a Wista w I tysiacleciu po Chr. [Natural traces of settlement changes between the Odra and Vistula in the first millennium after Chr.], [in:] A. Bursche et al. (ed.), Barbarzyńskie tsunami. Okres Wędrówek Ludów w dorzeczu Odry $i$ Wisty [Barbaric Tsunami. Migration Period in the Odra and Vistula basin], Warszawa-Szczecin, Uniwersytet Warszawski, Muzeum Narodowe w Szczecinie, 2017, pp. 17-23.

Lébedev G.S., Vernemsja $k$ nachalu [Back to the beginning], "Znanie - sila" ["Knowledge - Power"] 1986, No. 10, pp. 17-19. 
Leciejewicz L., Maty stownik kultury dawnych Stowian [A small dictionary of the culture of the old Slavs], Warszawa, Wiedza Powszechna, 1988.

Leciejewicz L., Stowianie Zachodni: z dziejów tworzenia się średniowiecznej Euro$p y$ [Western Slavs: from the history of the creation of medieval Europe], Wrocław, Ossolineum, 1989.

Łowmiański H., Początki Polski [Beginnings of Poland], Warszawa, PWN, 1963.

Łowmiański H., Scytia [Scythia], [in:] Stownik starożytności stowiańskich [Dictionary of Slavic antiquities], Vol. V, Wrocław, Ossolineum, 1975, pp. 101-119.

Łowmiański H., Studia nad dziejami Stowiańszczyzny, Polski i Rusi w wiekach średnich [Studies on the history of Slavdom, Poland and Rus in the Middle Ages], Poznań, Uniwersytet im. Adama Mickiewica w Poznaniu, 1986.

Luchinskij N.D. Tshineckij kul 'turnyj krug v probleme jetnogeneza slavjan [Tshinets culture in the problem of ethnogenesis of the Slavs], „Vestnik Moskovskogo gosudarstvennogo oblastnogo universiteta" ["Bulletin of Moscow State Regional University"] 2018, No. 2, pp. 89-96.

Machinskij D.A., Kuleshov V.S., Severnye narody serediny IV - pervoj poloviny VI v. v "Getica" Iordana [Northern peoples of the middle IV - first half of the 6th century in Jordanes' "Getica"], [in:] L. and G. Lebedev (ed.), Vos 'mye chtenija pamjati Anny Machinskoj [The Eighth Readings in memory of Anna Machinskaya], 2004, pp. 26-72.

Majewicz A.F., Języki świata i ich klasyfikowanie [Languages of the world and their classification], Warszawa, PWN, 1989.

Makiewicz T., $W$ sprawie aktualnego stanu badań nad problemem kontynuacji kulturowej pomiędzy starożytnościa a wczesnym średniowieczem $w$ Polsce. Punkt widzenia autochtonisty [On the current state of research on the problem of cultural continuity between antiquity and the early Middle Ages in Poland. The point of view of an autochthonist], "Slavia Antiqua: rocznik poświęcony starożytnościom słowiańskim" ["Slavia Antiqua: yearbook dedicated to Slavic antiquities"] 2005, No. 46, pp. 9-38.

Maksimov E.V., Migracii v zhizni drevnih Slavjan [Migrations in the life of the ancient Slavs], [in:] Slavjane i Rus' (V zarubezhnoj istoriografii) [Slavs and Rus (In foreign historiography)], Kiev, Naukova dumka, 1990, pp. 5-11.

Malaspina P. et al, Analysis of Y-chromosome variation in modern populations at the European-Asian border, [in:] Ancient Interactions: east and west in Eurasia, $\mathrm{K}$. Boyle et al. (ed.), McDonald Institute for Archaeological Research Monographs, Cambridge University, 2003, pp. 309-313.

Mańczak W., Zagadnienie praojczyzny Stowian [The question of the forehomland of Slavs], "Przegląd Historyczny" ["Historical Review"] 2003, No. 94(1), pp. 77-81. 
Matveev A.K., K probleme rasselenija letopisnoj meri (rus.) [To the problem of the settlement of the chronicle Merya (rus.)], "Izvestija Ural'skogo gosudarstvennogo universiteta" 1997, No.7, pp. 5-17.

Matveeva G.I., Nekotorye itogi izuchenija imen'kovskoj kul'tury [Some results of studying Imenkovskaya culture], [in:] Jetnogenez i jetnokul'turnye kontakty slavjan, Trudy VI Mezhdunarodnogo kongressa slavjanskoj arheologii [Ethnogenesis and ethnocultural contacts of the Slavs, Proceedings of the 6th International Congress of Slavic Archeology]. Vol. 3. Moskva, Nauka, 1997, pp. 206-217.

Matveeva G.I., Srednee Povolzh'e v IV-VII vv.: Imen 'kovskaja kul'tura [Middle Volga region in IV-VII centuries: Imenkovskaya culture], Samara, Samarskij universitet, 2004.

Mielnik-Sikorska M. et al., Genetic data from Y chromosome STR and SNP loci in Ukrainian population, "Forensic Science International: Genetics" 2013, No. 7, pp. 200-203.

Mielnik-Sikorska M. et al., The History of Slavs Inferred from Complete Mitochondrial Genome Sequences, https://journals.plos.org/plosone/article?id=10.1371/ journal.pone.0054360 [accessed: May 25, 2019].

Moczulski L., Geopolityka. Potęga w czasie i przestrzeni [Geopolitics. Power in time and space], Warszawa, Dom Wydawniczy Bellona, 1999.

Moszyński K., Badania nad pochodzeniem i pierwotna kultura Stowian [Research on the origin and primary culture of Slavs], Vol. I, Kraków, PAU, 1925.

Moszyński K., Badania nad pochodzeniem i pierwotna kultura Stowian [Research on the origin and primary culture of Slavs], „Rozprawy PAU” [Dissertations of the Polish Academy of Arts and Sciences], Vol. LXII, No. 2, Kraków 1925.

Moszyński K., Pierwotny zasiag języka prastowiańskiego [The original range of the Proto-Slavic language], Wrocław, Ossolineum, 1957.

Moszyński L., Wstęp do filologii stowiańskiej [Introduction to Slavic philology], Warszawa, PWN, 2006.

Mühle E., Die Slaven im Mittelalter [The Slavs in the Middle Ages], Berlin, De Gruyter, 2016.

Nalepa J., O pierwotnych siedzibach Stowian w świetle nowszych badań archeologicznych, lingwistycznych i historycznych [On the original premises of the Slavs in the light of newer archaeological, linguistic and historical researches], "Slavia Antiqua: rocznik poświęcony starożytnościom słowiańskim” 2007, No. 48, pp. 11-96.

Narasimhan V.M., The Genomic Formation of South and Central Asia, 2018, https:// www.biorxiv.org/content/early/2018/03/31/292581.full.pdf [accessed: May 25, 2019]. 
Neparáczki E. et al., 2019, Y-chromosome haplogroups from Hun, Avar and conquering Hungarian period nomadic people of the Carpathian Basin, https://www. biorxiv.org/content/biorxiv/early/2019/04/03/597997.full.pdf [accessed: May 25, 2019].

Noińska M., Genetyka populacyjna a problem etnogenezy Stowian [Population genetics and the problem of the ethnogenesis of the Slavs], "Studia Rossica Gedanensia" 2016, No. 3, pp. 143-156.

Oczko A., Zapożyczenia poludniowostowiańskie w języku rumuńskim w XVI i XVII wieku [South Slavic borrowings in Romanian in the 16th and 17th centuries], $\mathrm{PhD}$ thesis, Kraków, Uniwersytet Jagielloński, Wydział Filologiczny, https://ruj. uj.edu.pl/xmlui/bitstream/handle/item/41490/oczko_zapozyczenia_poludniowoslowianskie_w_jezyku_rumunskim_2010.pdf [accessed: May 25, 2019].

Okulicz Ł., Osadnictwo strefy wschodniobattyckiej w I tysiacleciu przed nasza era [Settlement of the Eastern Baltic zone in the first millennium BC], Wrocław, Ossolineum, 1976.

Parczewski M., Idzie nowe. Pierwsi Stowianie na ziemiach Polski [New is coming. First Slavs in Poland], [in:] A. Bursche et al. (ed.), Barbarzyńskie tsunami. Okres Wędrówek Ludów w dorzeczu Odry $i$ Wisty [Barbaric Tsunami. Migration Period in the Odra and Vistula basin], Warszawa-Szczecin, Uniwersytet Warszawski, Muzeum Narodowe w Szczecinie, 2017, pp. 59-65.

Parczewski M., Wspótczesne poglądy w sprawie etnogenezy oraz wielkiej wędrówki Stowian [Contemporary views on the ethnogenesis and the great migration of Slavs], [in:] M. Salamon i J. Strzelczyk (ed.), Wędrówka i etnogeneza w starożytności i w średniowieczu, Kraków, Historia Iagellonica, 2010, pp. 221-230.

Paszkiewicz H., Początki Rusi [The origins of Rus], Kraków, PAU, 1996.

Piontek J., Iwanek B., Segeda S., Antropologia o pochodzeniu Stowian [Anthropology about the origin of the Slavs], "Monografie Instytutu Antropologii UAM" 2008, No. 12.

Piskozub A., Jakiej monografii Odry nam potrzeba? Przestanki metodologiczne monografii wielkiej battyckiej rzeki [What kind of Odra monograph do we need? Methodological premises of the monograph on the great Baltic River], [in:] K. Schlögel, B. Halicka (ed.), Odra - Oder. Panorama europejskiej rzeki [OdraOder. Panorama of the European river], Skórzyn, Wydawnictwo Instytutowe, 2008, pp. 55-68.

Piskozub A., Między historiozofia a geozofia: szkice z filozofii czasoprzestrzeni ludzkiej [Between historiosophy and geosophy: sketches from the philosophy of the human space-time], Gdańsk, Uniwersytet Gdański, 1994. 
Pleszczyński A., Przekazy niemieckie o Polsce i jej mieszkańcach w okresie panowania Piastów [German messages about Poland and its inhabitants during the reign of the Piast], Lublin, Wydawnictwo UMCS, 2016.

Pliss L. et al., Y-Chromosomal Lineages of Latvians in the Context of the Genetic Variation of the Eastern-Baltic Region, "Annals of Human Genetics" 2015, No. 79(6), pp. 418-430.

Popowska-Taborska H., Wczesne dzieje Stowian w świetle ich języka [The early history of the Slavs in the light of their language], Wrocław-Kraków, Ossolineum, 1991.

Reich D., Who We Are and How We Got Here, Oxford, Oxford University Press, 2018.

Rębała K. et al., Contemporary paternal genetic landscape of Polish and German populations: from early medieval Slavic expansion to post-World War II resettlements, "European Journal of Human Genetics" 2013, No. 21(4), pp. 415-422.

Rębała K. et al., Y-STR Variation among Slavs: Evidence for the Slavic Homeland in the Middle Dnieper Basin, "Journal of Human Genetics" 2007, No. 52(5), pp. 406-414.

Ringe D., Warnow T., Taylor A., Indo-European and Computational Cladistics, "Transactions of the Philological Society" 2002, No. 100(1), pp. 59-129.

Rosser Z.H. et al., Y-chromosomal diversity in Europe is clinal and influenced primarily by geography, rather than by language, "American Journal of Human Genetics" 2000, No. 67(6), pp. 1526-1543.

Sedov V.V., Jetnogenez rannih Slavjan [Ethnogenesis of the early Slavs], "Vestnik Rossijskoj Akademii Nauk" ["Bulletin of the Russian Academy of Sciences"] 2003, No. 73(7), pp. 594-605.

Sedov V.V., Proishozhdenie i rannjaja istorija slavjan [The origin and early history of the Slavs], Moskva, Nauka, 1979.

Siatkowski J., Historia badań nad wptywami stowiańskimi na język niemiecki [The history of research on Slavic influences into German], „Gwary Dziś” [“Dialects Today"] 2015, No. 7, pp. 141-154.

Sielicki F. (transl. and elaboration), Nestor - Powieść minionych lat [Nestor - The Tale of Bygone Years], Wrocław, Ossolineum, 1999.

Skowronek J., Tanty M., Wasilewski T, Historia Stowian południowych i zachodnich [History of southern and western Slavs], Warszawa, PWN, 1988.

Sołtysiak A., Przyczyny ekspansji Stowian we wczesnym średniowieczu [Causes of the Slavs' expansion in the early Middle Ages], on-line, Stowarzyszenie „Niklot”, 24.04.2019, www.youtube.com/watch?v=klIkjWdrZmA [accessed: May 25, 2019]. 
Starostin S., Indo-European glottochronology and homeland. Paper presented at the Prehistoric Chronology Workshop, Santa Fe Institute, March 1-5, 2004.

Strzelczyk J., Goci. Rzeczywistość i legenda [Goths. Reality and legend], Poznań, Wydawnictwo Poznańskie, 2015.

Strzelczyk J., Od Prasłowian do Polaków [From Proto-Slaves to Poles], Kraków, KAW, 1987.

Strzelczyk J., Słowianie połabscy [Polabian Slavs], Poznań, Wydawnictwo Poznańskie, 2002.

Strzelczyk J., Słowianie w północno-wschodniej Bawarii w średniowieczu. Dzieje problemu [Slavs in north-eastern Bavaria in the Middle Ages. The history of the problem], "Acta Universitatis Nicolai Copernici. Historia" 1990, 24(204), pp. $155-174$.

Sykes B., Adam's Curse: A Future Without Men, London-New York, Bantam, 2003. Syrovatko A. S., Jugo-vostochnoe Podmoskov'e v zheleznom veke: $k$ harakteristike lokal'nyh variantov d'jakovskoj kul'tury [The southeastern suburbs in the Iron Age: on the characterization of local variants of Dyakovsk culture], Moskva, Izdatel'stvo CheBuk, 2009.

Tambets K. et al., The western and eastern roots of the Saami - the story of genetic "outliers" told by mitochondrial DNA and Y chromosomes, "American Journal of Human Genetics" 2004, No. 74(4), pp. 661-682.

Třeštík D., Powstanie Wielkich Moraw. Morawianie, Czesi i Europa Środkowa w latach 791-871 [The origin of the Great Moravia. Moravians, Czechs and Central Europe in 791-871], Warszawa, Wydawnictwa Uniwersytetu Warszawskiego, 2009.

Turlej S., Trwanie i zmiany. Stosunki etniczne na Bałkanach w okresie VI-X w. [Duration and changes. Ethnic relations in the Balkans during the 6th-10th century], [in:] M. Salamon i J. Strzelczyk (ed.), Wędrówka i etnogeneza w starożytności $i w$ średniowieczu [Wandering and ethnogenesis in ancient and medieval times], Kraków, Historia Iagellonica, 2010, pp. 251-267.

Tyszkiewicz J., Geografia historyczna Polski w średniowieczu [Historical geography of Poland in the Middle Ages], Warszawa, Wydawnictwo DiG, 2003.

Tyszkiewicz L.A., Słowianie i Awarowie. Organizacja plemienna Słowian [Slavs and Avars. Tribal organization of the Slavs], Wrocław, Ossolineum, 2009.

Tyszkiewicz L.A., Słowianie w historiografii antycznej do połowy VI wieku [Slavs in ancient historiography until the middle of the 6th century], Wrocław, Wydawnictwo Uniwersytetu Wrocławskiego, 1990.

Underhill P.A. et al., The phylogenetic and geographic structure of Y-chromosome haplogroup Rla, "European Journal of Human Genetics" 2014, No. 23(1), pp. 124-131. 
Wesołowski D. (Davidski), Rla-Z280 from Early Bronze Age Northern Poland, 2017, http://eurogenes.blogspot.com/2017/01/r1a-z280-from-early-bronze-agenorthern.html [accessed: May 25, 2019].

Wiślański T., Próba wyświetlenia genezy tzw. kultury amfor kulistych [An attempt to display the genesis of the so-called Globular Amphora culture], "Archeologia Polski” [“Archeology of Poland"]1963, No. 8(2), pp. 222-245.

Wojna R., Wielki świat nomadów. Między Chinami i Europa [The big world of nomads. Between China and Europe], Warszawa, Państwowe Wydawnictwo Wiedza Powszechna, 1983.

Zakrzewski S., Opis grodów i terytoriów z pótnocnej strony Dunaju czyli tzw. Geograf Bawarski [Description of castles and territories from the northern side of the Danube or the so-called Bavarian Geographer], Lwów, Towarzystwo dla Popierania Nauki Polskiej, 1917.

Zdziebłowski Sz., Nowe dowody na obecność ludzi na terenach Polski w późnej starożytności [New evidence for the presence of people in Poland in late antiquity], 2018, http://scienceinpoland.pap.pl/aktualnosci/news\%2C31468\%2Cnowedowody-na-obecnosc-ludzi-na-terenach-polski-w-poznej-starozytnosci.html [accessed: May 25, 2019].

Zhih M.I., Rannie slavjane v Srednem Povolzh'e (po materialam pis'mennyh istochnikov) [Early Slavs in the Middle Volga region (according to written sources)], SPb-Kazan', Vestfalika, 2011, 90 pp.

Zipser T., Rzeki w ksztaltowaniu się regionów [Rivers in the formation of regions], "Rzeki. Kultura - Cywilizacja - Historia" 1997, Vol. VI, pp. 107-122. 